\title{
Bio-Functional Design, Application and Trends in Metallic Biomaterials
}

\author{
Ke Yang ${ }^{1}$, Changchun Zhou ${ }^{2, *}$, Hongsong Fan ${ }^{2}$, Yujiang Fan ${ }^{2}$, Qing Jiang ${ }^{2}$, Ping Song ${ }^{3}$, \\ Hongyuan Fan ${ }^{3}$, Yu Chen ${ }^{4, *}$ and Xingdong Zhang ${ }^{2}$ \\ 1 School of Mechanical Engineering and Automation, Xihua University, Chengdu 610039, China; \\ yangke493@163.com \\ 2 National Engineering Research Center for Biomaterials, Sichuan University, Chengdu 610064, China; \\ hsfan@scu.edu.cn (H.F.); Fan_yujiang@scu.edu.cn (Y.F.); jiangq@scu.edu.cn (Q.J.); \\ zhangxd@scu.edu.cn (X.Z.) \\ 3 School of Manufacturing Science and Engineering, Sichuan University, Chengdu 610065, China; \\ 2016223025082@stu.scu.edu.cn (P.S.); fanhy@scu.edu.cn (H.F.) \\ 4 Department of Applied Mechanics, Sichuan University, Chengdu 610065, China \\ * Correspondence: changchunzhou@scu.edu.cn (C.Z.); yu_chen@scu.edu.cn (Y.C.); \\ Tel.: +86-28-85415123 (C.Z.); Fax: +86-28-85412848 (C.Z.)
}

Received: 9 November 2017; Accepted: 12 December 2017; Published: 22 December 2017

\begin{abstract}
Introduction of metals as biomaterials has been known for a long time. In the early development, sufficient strength and suitable mechanical properties were the main considerations for metal implants. With the development of new generations of biomaterials, the concepts of bioactive and biodegradable materials were proposed. Biological function design is very import for metal implants in biomedical applications. Three crucial design criteria are summarized for developing metal implants: (1) mechanical properties that mimic the host tissues; (2) sufficient bioactivities to form bio-bonding between implants and surrounding tissues; and (3) a degradation rate that matches tissue regeneration and biodegradability. This article reviews the development of metal implants and their applications in biomedical engineering. Development trends and future perspectives of metallic biomaterials are also discussed.
\end{abstract}

Keywords: metal implants; biomechanical design; porous structure; biodegradable metals; biological function design

\section{Introduction}

After the invention of stainless steel in the 19th century, metal implants have been well-developed and widely used in biomedical applications [1-4]. During the 1960s and 1970s, a first generation of metal materials was developed as implants. A common feature of these implants was their biological "inertness". Whereas, by the mid-1980s, bioactive materials had been proposed as second-generation biomaterials, in which biomaterials were designed to be either resorbable or bioactive $[5,6]$. Nowadays, more and more biofunctions are proposed for developing new generation of biomaterials which allow implants to interact with host tissues [7]. Regeneration properties become key feature for third-generation biomaterials, in which biomaterials are being designed to activate genes and cells to stimulate regeneration of living tissues [8]. The third-generation biomaterials combine multiple biological functions, with the aim of developing materials that, once implanted, will help the body heal or regenerate [9].

For metallic biomaterials, sufficient strength and inertness are two key features that should be considered in their early development [10]. Subsequently, the field of metallic biomaterials began to shift from inertness to bioactivity. This idea breaks old design principles for metallic biomaterials. 
More specific biofunctional designs in metallic biomaterials are proposed according to the application requirements [11,12]. Meanwhile, more design guidelines of metallic biomaterials need to be carefully considered. The first important issue is biomechanical design, including adequate mechanical properties such as strength, stiffness, and fatigue properties that are needed for appropriate design. Secondly, structure design and biological activation of metal implants are also crucial. Particularly, for bone tissue repair, surface bioactivation helps to integrate implants with host bones. Porous structure design is conducive to tissue growth and bone reconstruction. Thirdly, biodegradable design of metal implants is a new trend for regenerative tissue engineering. Biodegradable properties are important for novel metallic bone scaffolds or biodegradable stents. In many applications, implants are only needed temporarily and are expected to be biodegradable after supporting the healing process [13-17].

The biological functional design of metal implants is very important for clinical applications. Novel metal implants with different biological functions provide effective approaches for human tissue repair and regeneration. Innovative metal implant design and application are the most interesting issues in biomedical engineering. This paper reviewed three classic biological designs and applications of metal implants. It contains three main parts, the first part introduces the biomechanical design of metal implants, then porous structure design and biological activation of metal implants are introduced. Finally, as a new trend for regenerative engineering, the biodegradable design of metal implants is discussed. The state of the art of biodegradable metals, and their application for orthopedic and cardiovascular implants are reviewed. The future direction for metallic implants goes towards the combination of suitable mechanical property and bio-functionality. The study of innovative metallic implants is one of the most interesting research topics at the forefront of biomaterials.

\section{Different Applications of Metal Implants in Clinic}

Metal implants have been used for long time in the clinic. Metal implants are mainly used for hard tissue repair due to their excellent mechanical properties [18-20]. For example, titanium alloys are widely used in maxillofacial hard tissue repair. The complex stress state of maxillofacial bone tissues requires metal implants with matching mechanical properties to support mandibular functions $[21,22]$. Spine cages need metal implants with good osseointegration and high compressive strength to meet the needs of human movement. Hence, these implants were usually designed into porous structures to improve osseointegration and adjust mechanical strength [23,24]. For orthopedic implants, the biocompatibility and mechanical strength are critical concern issues. For stents which are hemolytic and bioabsorbable properties need to be carefully considered. Figure 1 shows several typical applications for metal implants.

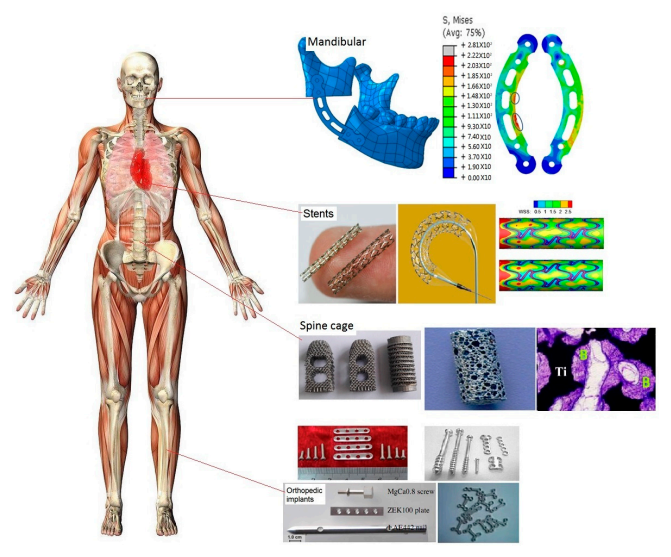

Figure 1. Different clinic applications for metal implants. Metal implants are mainly used in stents and hard tissue repair, which includes maxillofacial, spine and orthopedic fixation implants. WSS: wall shear stress; B: new bones. 


\subsection{Biomechanical Design of Metal Implants}

The first important property of metal implants is the biomechanical design, including suitable mechanical properties such as strength, stiffness, wear, corrosion resistances and fatigue properties that need to be carefully designed [25-29]. A great number of researchers are still working on this field of biomechanical design to resolve various issues being faced today [30-35]. Biocompatibility and mechanical properties of metal implants are the most crucial properties for both temporary and permanent implants [36]. For metal implant mechanical design, biocorrosion plays an important role, especially when metal implants are used in load-bearing sites, such as screws for internal fixation of bone fractures [37-39]. In order to sustain pressurized loads, they must be stiff and able to resist deformation. Metal implants must also be light to facilitate motion [40-42].

3D finite element modeling is a useful method which allows the analysis of the spatial stress of implants, and it has been widely used for the quantitative evaluation of stress spatial distribution on the implant. Tang et al. [43] proved the feasibility of topology optimization in the repair of mandibular defect and obtained a more mechanically suitable configuration of a titanium reconstruction plate, and provided suggestions for choosing and constructing the repairing configuration of mandibular defects in clinical treatment. The topology optimization on the configuration of a titanium reconstruction prosthesis is shown Figure 2.

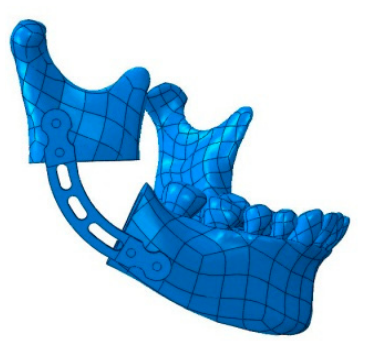

(a)

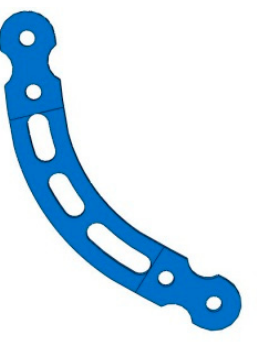

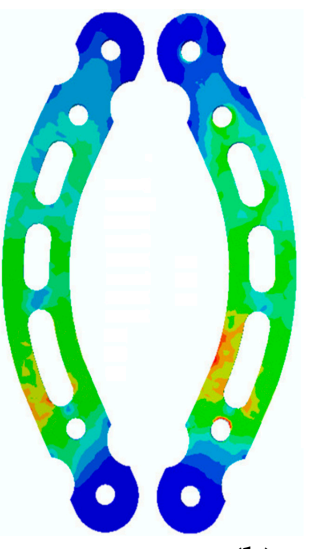

(b)

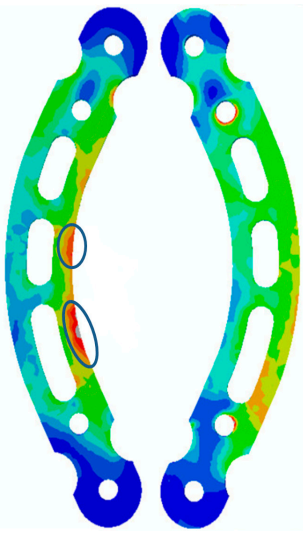

Figure 2. (a) Left: Models and grid; Right: a titanium reconstruction prosthesis. (b) The distribution of the strain of the von Mises on titanium prosthesis in different working conditions.

Guo et al. [44] investigated stress and bone density distribution changes in the mandible due to the interference fit in titanium dental implants for mandible reconstruction, and studied the influence of interference magnitudes on mandibular bone remodeling.

3D print metal technology has been developed in the field of medical bone implantation, Wan et al. [45] found stress concentration coefficients are significantly different for three distribution forms due to the difference of special location. Stress distribution of a single hole model is shown in Figure 3.

Stent implantation changed the intravascular hemodynamic environment, numerical methods were widely applied to the modeling of drug eluting stents and of their interaction with coronary arteries [46]. Chen et al. [47] compared different types of virtual drug-eluting stents (DESs) models with different links, geometries and curvatures, and analyzed the changes of hemodynamics and drug concentration caused by the implantation of three types of DESs with numerical simulation methods, including (1) the effects of DESs with different links on the drug concentration distribution; (2) the effects of DESs with different link numbers and geometries on the drug concentration distribution (as shown in Figure 4); (3) the effects of DESs with different curvature on the hemodynamics and drug 
concentration (as shown in Figure 5). Research on DESs provide valuable instructions and theoretical numerical conclusions that guide the design of DES (as shown in Figure 6) [47].
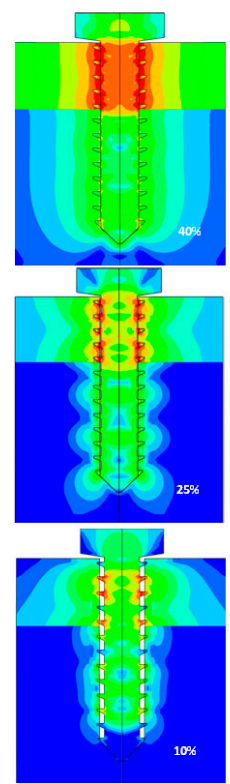
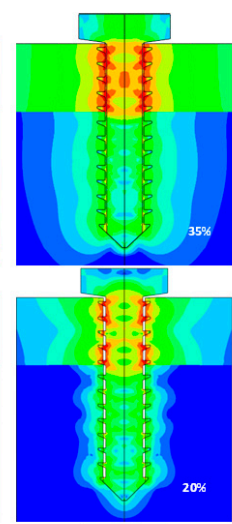

L.

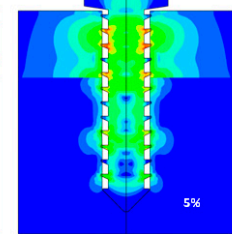

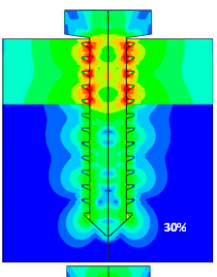
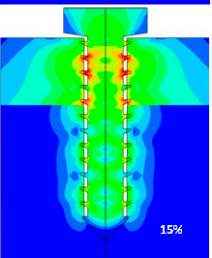

Stress $(\mathrm{MPa})$

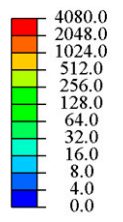

Figure 3. Von Mises stress distributions in models with different interference magnitudes after immediate implantation of titanium screw.

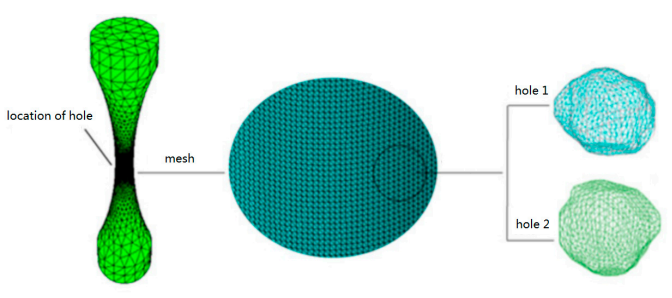

(a)

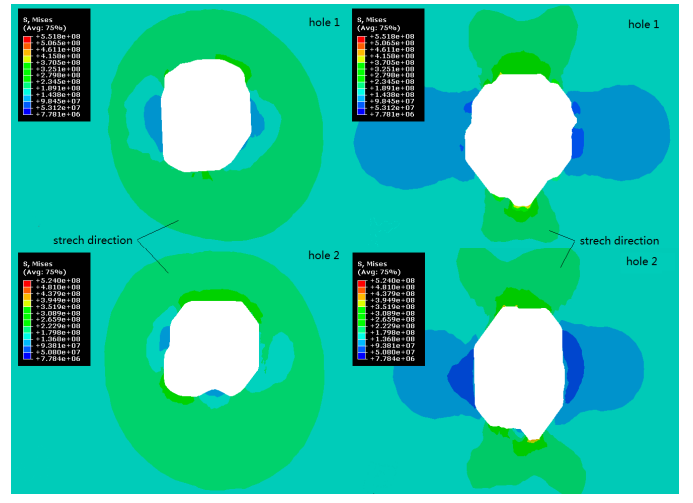

(b)

Figure 4. (a) Hole implantation and mesh generation; (b) Stress distribution of single hole model.

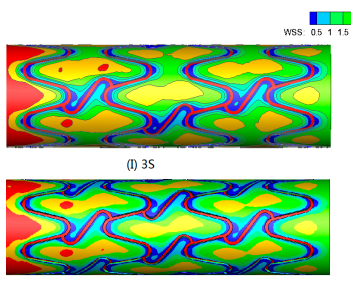

(III) 65

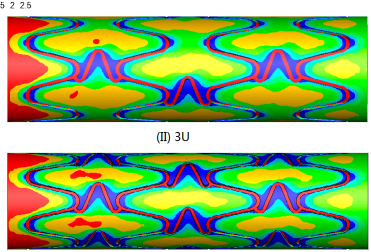

(a)

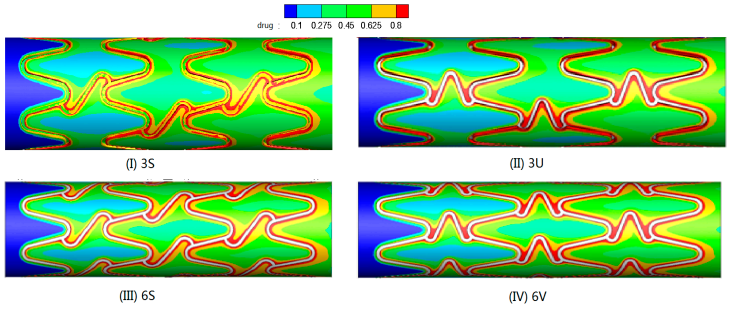

(b)

Figure 5. The distribution of WSS/drug concentration in different links DESs. (a) Wall shear stress (WSS), (I): Three S-type links, (II): Three U-type links, (III): Six S-type links, (IV): Six U-type links. (b) Drug concentration, (I): Three S-type links, (II): Three U-type links, (III): Six S-type links (IV): Six U-type links. 


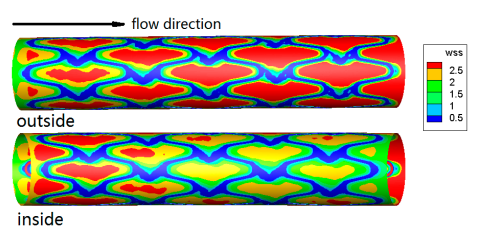

(a)

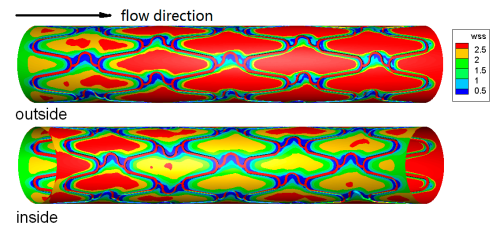

(b)

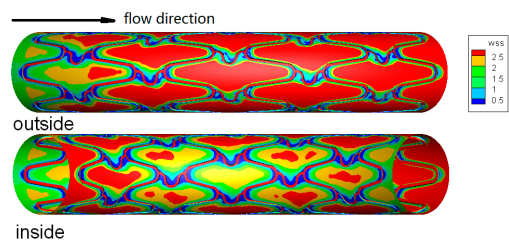

(c)

Figure 6. The distribution of WSS in different curvatures DESs. (a) $30^{\circ}$; (b) $60^{\circ}$; (c) $90^{\circ}$.

Changes of hemodynamics caused drug deposition and distribution on arterial walls, Chen et al. [48] analyzed four different coated models, and found drug coating on the contacting surface can provide effective drug release in the vascular wall without the interference from blood flow (as shown in Figure 7). It is possible to improve the uniformity of drug concentration in the vascular wall through optimal design of drug loading on the contacting surface.

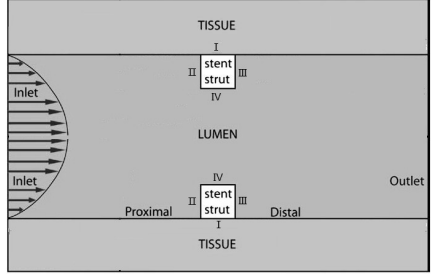

(a)

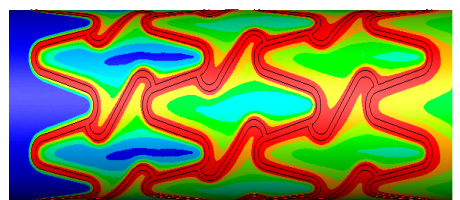

(i) All-Coated

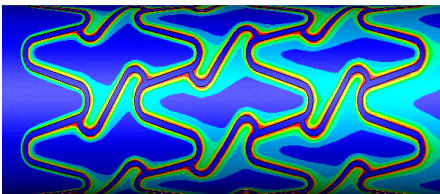

(iii) II and III-Coated

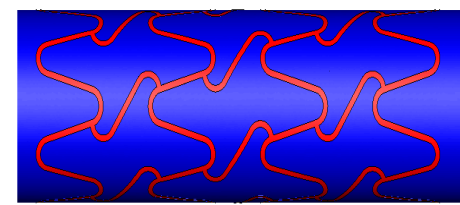

(ii) I-Coated

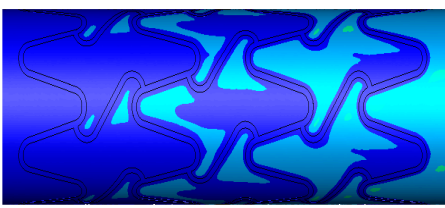

(iv) IV-Coated

(b)

Figure 7. (a) Drug-coated Schematic diagram, the drug-eluting stent is nickel-titanium alloy and drug coated with rapamycin; (b) The drug distribution of four coated designs.

\subsection{Porous Structure Design and Biological Activation of Metal Implants}

\subsubsection{Porous Structure Design and Manufacturing}

For bone tissue substitutes, porous structure design and its manufacturing are very important for metal implants [49-51]. Porous architectures have effects on cell distribution and migration, as well as in vivo blood vessel formation, tissue ingrowth and sustaining new bone formation [52]. Recently, some advanced manufacturing technology have been proposed in biodegradable metal (BM) fields. For instance, by using 3D printing technology, the metals can be directly processed into scaffolds or implants [53-56]. In order to fabricate bone scaffolds, three-dimensional (3D) porous structures have been pursued to allow for bone ingrowth, to mimic the natural porous structure of bone. It has been possible to create a controllable porous, interconnected architecture via 3D printing technology. By using 3D printing, complex, customizable parts from metal powders can be directly manufactured into scaffolds with precise porosity [49,57-60]. Studies have indicated that the printed scaffolds demonstrated tensile mechanical property values very similar to those of natural bone, indicating its promise for bone replacement. Based on these preliminary studies, researchers believe that $3 \mathrm{D}$ printing will be a promising technology for manufacturing BM products [61-63]. Figure 8 shows some porous orthopedic implants fabricated by 3D printing technology. 

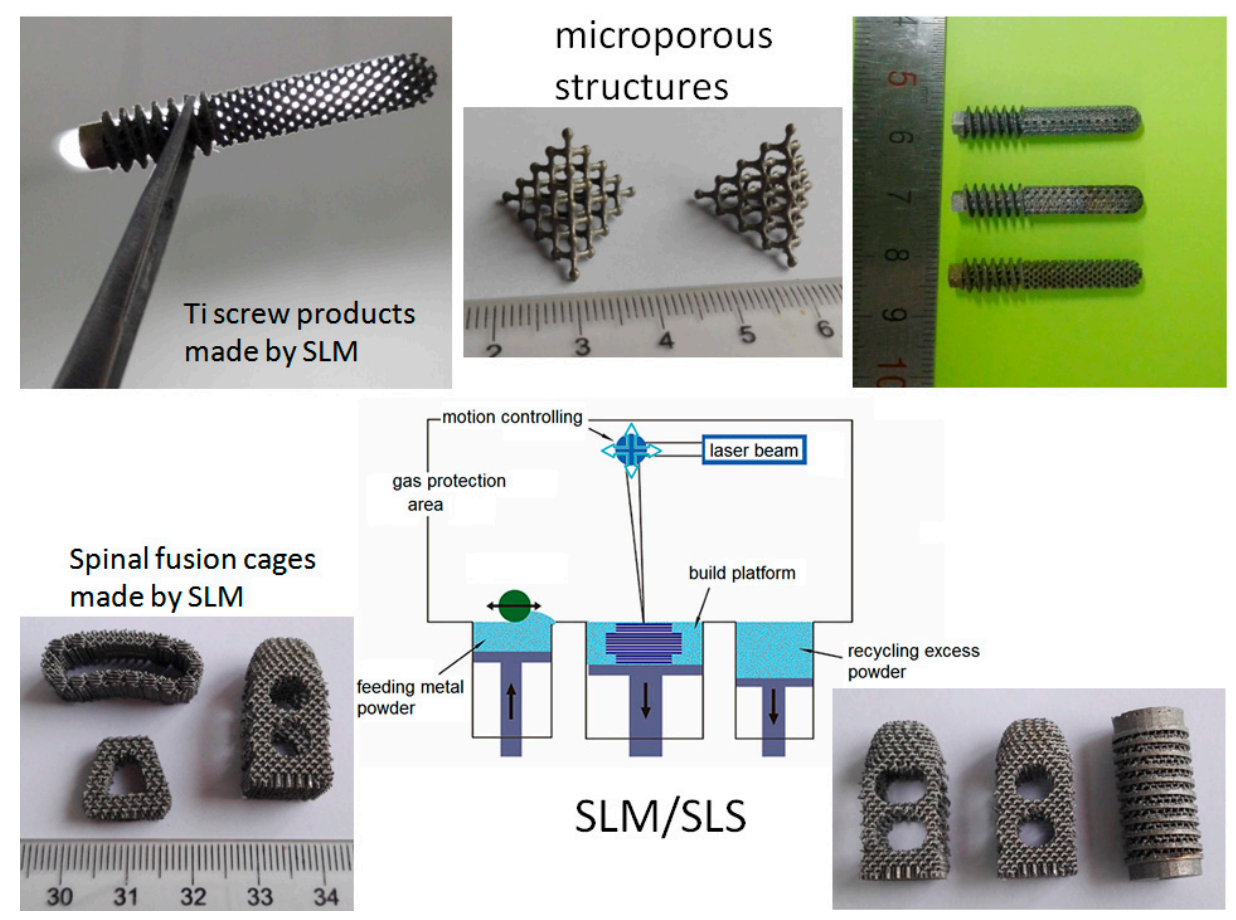

Figure 8. Some porous orthopedic implants fabricated by selective laser melting or selective laser sintering (SLM/SLS) technology. The upward arrow in SLM/SLS indicates that the platform of the printer is pushed up to provide print powders, and the downward arrows indicate the platform drop to recycle the print powders, bidirectional arrow means reciprocating pave the print powders.

\subsubsection{Biological Activation of Metal Implants}

Biological activation of metal implants is another important issue for biomedical product applications [64-67] because every metal implant combined/integrated with host tissues through a bioactive interface or layer. It was found that certain biomaterials can bond to living bone through an apatite layer that forms on surfaces after being implanted [68]. As bioactive implants, the formation of bone-like apatite interface ability is an important factor for osteoinduction. It was well reported that a metal implant able to form the apatite on its surface in the living body is able to bond to living bone through the apatite layer, but an implant unable to form the surface apatite does not bond to host bones [69-72]. Therefore, many metal implant surface modifications were done to meet expected surface activation so that implants can bond to host bone tissues.

It has been proven that metal implants bond to living bone through an apatite layer that forms on their surfaces in the living body [73]. Since the 1980s, it has been reported that metals could be osteoinductive biomaterials through specific chemical and thermal surface treatments. Many studies reported that certain metal oxide gels, such as $\mathrm{TiO}_{2}, \mathrm{ZrO}_{2}, \mathrm{Nb}_{2} \mathrm{O}_{5}$, and $\mathrm{Ta}_{2} \mathrm{O}_{5}$ form the apatite on their surfaces in simulated body fluid (SBF) within a week. Metallic materials are generally covered with a thin oxide layer. These metals have bone-like apatite formation abilities on their surface, which means they have bioactivity [74]. Various surface modifications were applied to metal implants for inducing bone-bonding bioactivity, such as acid treatment, alkali or alkali-heat treatment, acid-alkali treatment, hydrogen peroxide treatment, anodic oxidation, electrochemical reaction and hydrothermal treatments. These methods are mainly based on chemical or electrochemical reactions occurring at the interface between the metal and surrounding solution. The mechanism of apatite formation can be explained as the electrostatic interaction between $\mathrm{M}-\mathrm{OH}$ functional groups on the film and $\mathrm{Ca}^{2+}, \mathrm{PO}_{4}{ }^{3-}$ ions in the simulated body fluid between the metal and apatite [75-77].

Titanium and its alloys are the most widely used metal implants in orthopedic applications because of their good compatibility with living tissue [78]. Titanium was reported to show super 
apatite-forming ability, which allows them to directly bond to living bone in vivo [76,79]. However, in most cases, the bioactive properties only occur when appropriate surface treatments are conducted to modify and activate the metal surface. Surface treatments may change the surface microstructure and chemical composition of titanium. Porous titanium with different surface treatments showed excellent ability to induce bone-like apatite formation, and thus possessed in vitro bioactivity. For example, six types of surface treatments including $\mathrm{NaOH}$ treatment (NTPT), acid-alkali treatment (AAPT), hydrogen peroxide treatment (HOPT), hydrogen peroxide solution containing tantalum chloride treatment (HTPT) and chemical and thermal treatment (CTPT) performed on porous titanium showed different bone-like apatite-forming ability and in vivo osteoinductivity. By dorsal implanting for three and five months, ectopic bone formation was found histologically in most porous titanium scaffolds after implantation in the thighbone of adult dogs for two months (as shown in Figure 9). The osteoinduction phenomenon was found in porous Ti metals subjected to HOPT, HTPT and CTPT treatments. However, no obvious osteoinduction phenomenon was observed in NTPT and AAPT specimens. These results demonstrated that specific surface treatments could endow porous titanium with apatite-forming ability, and induce new bone formation [80].

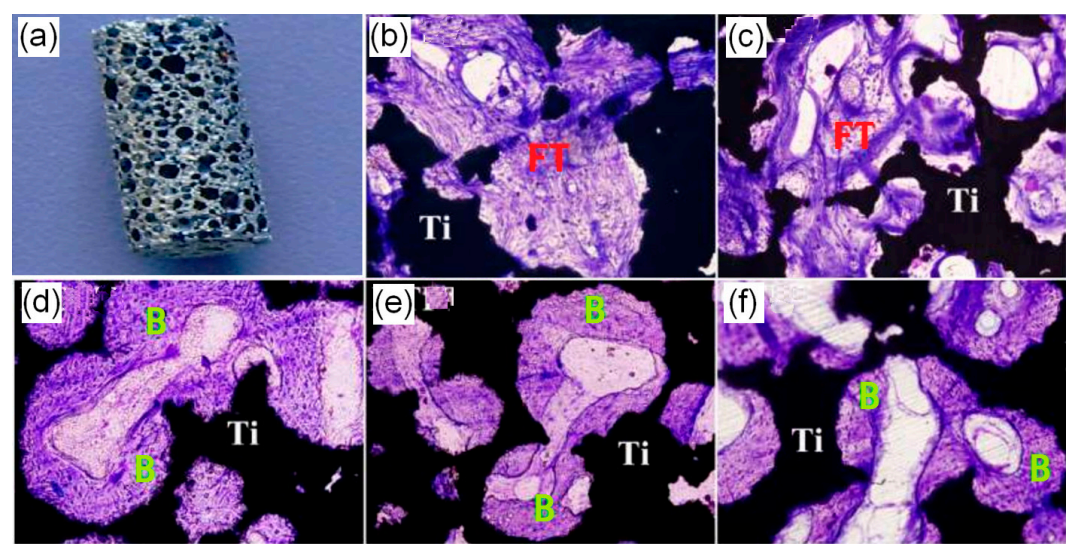

Figure 9. The osteoinduction phenomenon of in porous Ti metals. (a) is the porous Ti specimen, (b) is the histological observation after the Ti specimen subjected to $\mathrm{NaOH}$ treatment (NTPT), (c) is acid-alkali treatment (AAPT) specimen, (d) is hydrogen peroxide treatment (HOPT) specimen, (e) and (f) are hydrogen peroxide solution containing tantalum chloride treatment (HTPT) and chemical and thermal treatment (CTPT) specimens. Toluidine blue dye; FT: fiber texture; B: new bones; magnification: $200 \times$.

\subsection{Biodegradable Design for Metal Implants}

Traditional metallic biomaterials require metals with sufficient strength and improved corrosion resistance in the body. However, with recent development in biomaterials, the new concept of biodegradable metals (BMs), rather than inert biomaterials, has been dramatically developed [81-83]. In these applications, metals need only to temporary support the healing process, and thereafter to be degraded in regenerative engineering [84,85].

Degradation Mechanism of Metal Implants

As a key property for biodegradable metals, biodegradation rate should be carefully considered. The corrosion mechanisms and their influencing factors of biodegradable metals have been widely studied $[83,86]$. Classic degradation of BMs is mainly explained as electrochemical corrosion in vitro. Corrosion reactions of metal implants involve the following anodic dissolution of the metal in physiological environment, the corresponding degradation reactions are given in Equations (1)-(4):

$$
\text { Oxidation reaction: } \mathrm{M} \rightarrow \mathrm{M}^{\mathrm{n}+}+\mathrm{ne}^{-}
$$




$$
\begin{gathered}
\text { Reduction reaction: } 2 \mathrm{H}_{2} \mathrm{O}+2 \mathrm{e}^{-} \rightarrow \mathrm{H}_{2}(\mathrm{~g})+2 \mathrm{OH}^{-} \\
\text {Reduction reaction: } 2 \mathrm{H}_{2} \mathrm{O}+\mathrm{O}_{2}+4 \mathrm{e}^{-} \rightarrow 4 \mathrm{OH}^{-} \\
\text {Product formation reaction: } \mathrm{M}^{\mathrm{n}+}+\mathrm{nOH}^{-} \rightarrow \mathrm{M}(\mathrm{OH})_{\mathrm{n}}
\end{gathered}
$$

The electrochemical corrosion reaction happen when the metal implants react with body fluid. In the oxidation reaction, the metals give away electrons and form positive ions. In reduction reactions, the body fluid medium obtains electrons as cathelectrode. From a chemical point of view, the biological environment is highly soluble for BMs, especially due to the presence of high concentrations of chloride ions in blood plasma. The biological environments have great effects on BM corrosion reactions. The corrosion mechanism and apatite formation process of BMs under human biological environments are shown as Figure 10. Ions present in the biological environment may strongly accelerate to the corrosion process.
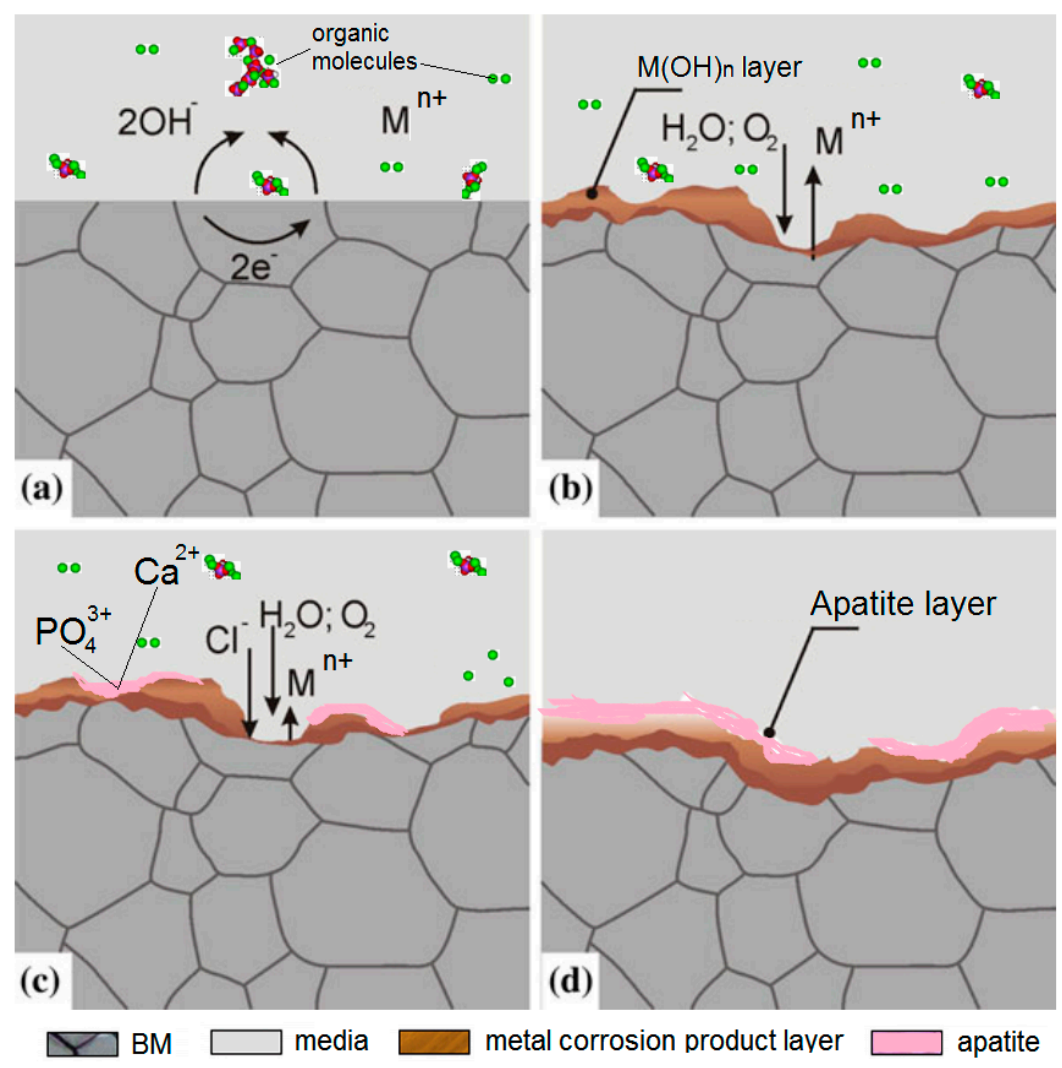

Figure 10. The explanation of degradation and apatite formation process on the surface of biodegradable metals (BMs). (a) is the metal implants just contact with body fluid, the oxidation-reduction reaction happened, the metals give away electrons formed anode, and the body fluid medium obtains electrons as cathelectrode; $(\mathbf{b})$ is the corrosion happened and the metal corrosion product layer generated; (c) is the apatite layer formed and (d) is the final surface of the BMs.

\section{Different Types of Biodegradable Metal Implants}

Nowadays, different types of biodegradable metal implants have been well-developed and applied in clinical applications [13,87-91]. However, three main types of materials are mostly studied: (i) Mg-based BMs. (ii) Fe-based BMs. and (iii) Zn-based BMs. Among these BMs, Mg-based BMs are the most popular and have reported in many publications [92,93]. Fe-based BMs were reported recently in alloy design, and some animal testing was conducted for potential vascular stents. Zn-based BMs are less studied by researchers but seem to be promising candidates in the family of BMs. Table 1 
shows some recent research progress of the three BM systems. Most research is focused on controlling the degradation rate, the in vitro cytotoxicity and animal testing.

Table 1. Research progress in Mg-based, Fe-based and Zn-based biodegradable metal implants.

\begin{tabular}{|c|c|c|c|c|}
\hline Types of BMs & Materials & $\begin{array}{l}\text { Published } \\
\text { Time }\end{array}$ & Progress \& Findings & $\begin{array}{c}\text { Potential } \\
\text { Applications }\end{array}$ \\
\hline \multirow{12}{*}{ Mg-based BMs } & ZEK100 [94] & 2017 & $\begin{array}{l}\text { Biodegradable behavior of } \\
\text { ZEK100 with various loading } \\
\text { conditions were studied. }\end{array}$ & $\begin{array}{c}\text { No } \\
\text { declaration }\end{array}$ \\
\hline & ZEK100 [95] & 2016 & $\begin{array}{l}\text { Multilayered coatings carrying } \\
\text { sodium alginate (ALG) were } \\
\text { placed on ZEK100 to reduce the } \\
\text { degradation rate. }\end{array}$ & $\begin{array}{l}\text { Bone tissue } \\
\text { repair }\end{array}$ \\
\hline & $\begin{array}{l}\text { Mg-Zn-Ca-Sr bulk } \\
\text { metallic glasses } \\
\text { (BMGs) [96] }\end{array}$ & 2016 & $\begin{array}{l}\text { In vitro responses of } \\
\text { bone-forming MC3T3-E1 } \\
\text { pre-osteoblasts to } \mathrm{Mg}-\mathrm{Zn}-\mathrm{Ca}-\mathrm{Sr} \\
\text { BMGs were studied. }\end{array}$ & $\begin{array}{c}\text { No } \\
\text { declaration }\end{array}$ \\
\hline & $\begin{array}{l}\mathrm{Mg}-3 \text { wt \% Zn alloy } \\
\text { (MZ3) [97] }\end{array}$ & 2016 & $\begin{array}{l}\text { Hot rolled Mg- } 3 \text { wt \% Zn alloy } \\
\text { (MZ3) has been investigated for } \\
\text { its potential in orthopaedic } \\
\text { implant. }\end{array}$ & $\begin{array}{l}\text { Orthopaedic } \\
\text { implantations }\end{array}$ \\
\hline & Mg-8Er-1Zn [98] & 2015 & $\begin{array}{l}\text { A novel Mg- } 8 \mathrm{Er}-1 \mathrm{Zn} \text { alloy with } \\
\text { the ultimate tensile strength ( } 318 \\
\mathrm{MPa}) \text {, tensile yield strength ( } 207 \\
\mathrm{MPa}) \text { and elongation }(21 \%) \text { were } \\
\text { reported. }\end{array}$ & $\begin{array}{c}\text { No } \\
\text { declaration }\end{array}$ \\
\hline & $\mathrm{Mg}-\mathrm{Zn}-\mathrm{Ca}-\mathrm{Sr}$ alloy [99] & 2015 & $\begin{array}{l}\text { Add minor Sr would improve } \\
\text { glass-forming ability, } \\
\text { mechanical properties, enhance } \\
\text { and adjustable corrosion } \\
\text { performance. }\end{array}$ & $\begin{array}{l}\text { Orthopedic } \\
\text { implantations }\end{array}$ \\
\hline & Mg60Zn35Ca5 [100] & 2015 & $\begin{array}{l}\text { Used first-principles molecular } \\
\text { dynamics simulations to } \\
\text { elucidate the structure of } \\
\text { Mg60Zn35Ca5. }\end{array}$ & $\begin{array}{c}\text { No } \\
\text { declaration }\end{array}$ \\
\hline & $\begin{array}{l}\text { Nano-hydroxyapatite } \\
\text { (nHA) reinforced } \\
\text { AZ31 [101] }\end{array}$ & 2014 & $\begin{array}{l}\text { Embedded nano-hydroxyapatite } \\
\text { (nHA) particles enhance the } \\
\text { biomineralization and control } \\
\text { the degradation. }\end{array}$ & $\begin{array}{l}\text { Skeletal } \\
\text { implants }\end{array}$ \\
\hline & AZ31 [102] & 2014 & $\begin{array}{l}\text { Surface coating for } \mathrm{Mg} \text { alloy } \\
\text { AZ31 to control its corrosion } \\
\text { rate. }\end{array}$ & Stents \\
\hline & AZ31 [102] & 2014 & $\begin{array}{l}\text { Report a new surface coating for } \\
\text { Mg alloy AZ31 based on a } \\
\text { low-toxicity ionic liquid, } \\
\text { tributyl(methyl)phosphoniumdiph } \\
\text { to control its corrosion rate. }\end{array}$ & $\begin{array}{l}\text { Stents } \\
\text { ienylphosphate, }\end{array}$ \\
\hline & RS66 [103] & 2013 & $\begin{array}{l}\text { In vitro and in vivo experiments } \\
\text { were conducted to analyze the } \\
\text { biodegradation behavior and } \\
\text { the biocompatibility. }\end{array}$ & $\begin{array}{l}\text { Prosthesis } \\
\text { implantation }\end{array}$ \\
\hline & Mg-Zn [104] & 2011 & $\begin{array}{l}\text { Biocompatibility test and } \\
\text { biodagradation in vivo. }\end{array}$ & $\begin{array}{l}\text { Orthopaedic } \\
\text { implantations }\end{array}$ \\
\hline
\end{tabular}


Table 1. Cont.

\begin{tabular}{|c|c|c|c|c|}
\hline Types of BMs & Materials & $\begin{array}{l}\text { Published } \\
\text { Time }\end{array}$ & Progress \& Findings & $\begin{array}{c}\text { Potential } \\
\text { Applications }\end{array}$ \\
\hline \multirow{8}{*}{ Fe-based BMs } & $\begin{array}{c}(\mathrm{Fe} 0.75 \mathrm{~B} 0.15 \mathrm{Si} 0.1) 100- \\
\mathrm{xNbx}(\mathrm{x}=0,1 \text { and } 3 \\
\mathrm{wt} \%)[105]\end{array}$ & 2016 & $\begin{array}{l}\text { Alloys exhibit excellent } \\
\text { apatite-forming ability in } \\
\text { simulated body fluids. }\end{array}$ & $\begin{array}{l}\text { Stents and } \\
\text { orthopedic } \\
\text { implants }\end{array}$ \\
\hline & $\begin{array}{l}\text { Fe-based glassy } \\
\text { alloys [106] }\end{array}$ & 2016 & $\begin{array}{l}\text { It studied the multiple corrosion } \\
\text { potentials in alkaline solution. }\end{array}$ & $\begin{array}{c}\text { No } \\
\text { declaration }\end{array}$ \\
\hline & $\begin{array}{l}\text { Fe-based metallic } \\
\text { materials [107] }\end{array}$ & 2015 & $\begin{array}{l}\text { Cytotoxicity of corrosion } \\
\text { products of Fe-based stents } \\
\text { relevant of } \mathrm{pH} \text { and insoluble } \\
\text { products were studied. }\end{array}$ & Stents \\
\hline & $\begin{array}{l}\text { Fe80-x-yCrxMoyP13C7 } \\
\text { bulk metallic } \\
\text { glasses [108] }\end{array}$ & 2015 & $\begin{array}{l}\text { Alloys exhibit no cytotoxicity to } \\
\text { NIH3T3 cells, and exhibit high } \\
\text { corrosion resistance and } \\
\text { excellent biocompatibility. }\end{array}$ & $\begin{array}{c}\text { No } \\
\text { declaration }\end{array}$ \\
\hline & $\begin{array}{c}(\mathrm{Fe}-10 \mathrm{Mn}-1 \mathrm{Pd}, \mathrm{Fe}-21 \\
\mathrm{Mn}-0.7 \mathrm{C}-1 \mathrm{Pd})[109]\end{array}$ & 2014 & $\begin{array}{l}\text { The study investigated the } \\
\text { degradation performance of } \\
\text { three Fe-based materials in a } \\
\text { growing rat skeleton over } 1 \text { year. }\end{array}$ & $\begin{array}{c}\text { No } \\
\text { declaration }\end{array}$ \\
\hline & Fe-Mn-C-Pd alloys [110] & 2013 & $\begin{array}{l}\text { The research studied the } \\
\text { alloying elements' influence on } \\
\text { metabolic processes. }\end{array}$ & $\begin{array}{c}\text { No } \\
\text { declaration }\end{array}$ \\
\hline & Fe-Mn-Pd alloys [111] & 2010 & $\begin{array}{l}\text { Fe-based alloys offering both an } \\
\text { enhanced degradation rate and } \\
\text { suitable strength and ductility. }\end{array}$ & $\begin{array}{c}\text { Medical } \\
\text { applications }\end{array}$ \\
\hline & $\begin{array}{l}\mathrm{Fe}(73.5) \mathrm{Si}(13.5) \mathrm{B} 9 \mathrm{Nb} 3 \mathrm{Cu} 1 \\
\text { alloy [112] }\end{array}$ & 2010 & $\begin{array}{l}\text { Studied the corrosion behaviors } \\
\text { of amorphous and } \\
\text { nanocrystalline Fe-based alloys } \\
\text { in } \mathrm{NaCl} \text { solution }\end{array}$ & $\begin{array}{c}\text { No } \\
\text { declaration }\end{array}$ \\
\hline \multirow{5}{*}{ Zn-based BMs } & $\begin{array}{l}\mathrm{Zn}-\mathrm{Mg} \text { and two } \\
\mathrm{Zn}-\mathrm{Al} \text { binary } \\
\text { alloys [113] }\end{array}$ & 2016 & $\begin{array}{l}\text { Alloys were fabricated by } \\
\text { casting process and hot } \\
\text { extrusion. Tube extrusion was } \\
\text { applied to produce stents. } \\
\text { Corrosion tests were performed. }\end{array}$ & Stents \\
\hline & Zn-Mg alloy [114] & 2015 & $\begin{array}{l}\mathrm{Zn}-\mathrm{Mg} \text { alloys with different } \mathrm{Mg} \\
\text { contents were prepared by } \\
\text { melting-casting method. The } \\
\mathrm{Zn}-3 \mathrm{wt} \% \mathrm{Mg} \text { alloy contributes } \\
\text { to a general corrosion. }\end{array}$ & $\begin{array}{c}\text { No } \\
\text { declaration }\end{array}$ \\
\hline & Zn alloys [115] & 2013 & $\begin{array}{l}\text { Zinc exhibits ideal physiological } \\
\text { corrosion behavior for } \\
\text { bioabsorbable stents. }\end{array}$ & Stents \\
\hline & $\begin{array}{l}\text { CaZn based bulk } \\
\text { glassy alloy [116] }\end{array}$ & 2011 & $\begin{array}{l}\text { CaZn based glassy alloys shows } \\
\text { low Young's modulus, high } \\
\text { fracture strength, good } \\
\text { corrosion resistance and } \\
\text { cytocompatibility. }\end{array}$ & $\begin{array}{l}\text { Orthopaedic } \\
\text { implantations }\end{array}$ \\
\hline & $\begin{array}{l}\text { Zn-Mg alloys } \\
\text { containing } 3 \text { wt \% } \\
\text { Mg [117] }\end{array}$ & 2011 & $\begin{array}{l}\text { The corrosion rates of the } \\
\mathrm{Zn}-\mathrm{Mg} \text { alloys were determined } \\
\text { to be significantly lower than } \\
\text { those of } \mathrm{Mg} \text { and } \mathrm{AZ} 91 \mathrm{HP} \text { alloys. }\end{array}$ & $\begin{array}{c}\text { No } \\
\text { declaration }\end{array}$ \\
\hline
\end{tabular}




\subsection{Applications of Magnesium-Based BMs}

Mg-based BMs have been successfully used because of their good biodegradable properties and biocompatibilities. Magnesium is an important element of the human body; an adult normally needs a daily intake of 300-400 mg magnesium. In blood plasma, $\mathrm{Mg}$ can be tolerated up to 85-121 mg/L [118]. Magnesium is also an essential element in bone tissue and it is beneficial to bone strength and growth. Promising Mg alloying systems including $\mathrm{Mg}-\mathrm{Zn}, \mathrm{Mg}-\mathrm{Ca}, \mathrm{Mg}-\mathrm{Sr}, \mathrm{Mg}-\mathrm{Si}, \mathrm{Mg}-\mathrm{RE}, \mathrm{Mg}-\mathrm{Mn}$ and $\mathrm{Mg}-\mathrm{Ag}$ have been well developed and investigated [84,119]. The manufacturing, microstructures, mechanical and biodegradable properties have been widely explored [120-123]. Magnesium alloys have excellent mechanical properties which have a large range of ultimate tensile strength (86.8-300 MPa) and elongation to failure (3-30\%), respectively. Usually, Mg-based BMs degrade very quickly in the human body. The rapid degradation rate may cause the scaffolds to collapse shortly after implantation. Therefore, adding other alloying elements, microstructure adjustment and surface modification methods have been applied to control the biodegradation rate of $\mathrm{Mg}$-based implants [81]. Addition of alloying elements, for example, adding Zn, Y, Ca, RE and Mn as alloying elements in WE43, ZW21 and WZ21, which may improve their corrosion resistance and generate exceptional plasticity of $17 \%$ and 20\% [124]. These modified alloys exhibited fairly homogeneous slower degradation behavior in body fluids.

Some other methods such as mechanical deformation were used to improve the corrosion properties of Mg-based BMs. It has been reported that plastic deformation methods such as rolling, extrusion, drawing, forging and high pressure torsion can dramatically improve $\mathrm{Mg}$ alloys, mechanical properties and corrosion behaviors $[13,125,126]$. Surface modification and composition methods are also effective to control the biodegradation rate of Mg alloys. For example, AZ91D with hydroxyapatite (HA) coatings can slow down its corrosion process in SBF. AZ91 samples with coated polycaprolactone (PCL) layer can reduce their degradation rate.

\subsection{Applications of Fe-Based BMs}

Fe-based BMs are also good candidates for biodegradable stent applications because of their high strength ( $1450 \mathrm{MPa}$ ) and high ductility ( $80 \%$ elongation). High strength is favored for making Fe-based stents with smaller shape which is good for operation. High ductility is very important for expansion during the implantation of stents. However, Fe-based BMs show lower degradation rates [127]. Some attempts have been performed to accelerate the degradation rate of Fe-based BMs. For example, Mn, Pd, W, Sn, B, C, S and Si elements were introduced into alloys to accelerate their degradation rate. After adding Si into alloys, the corrosion rate of $\mathrm{Fe}_{30} \mathrm{Mn}_{6} \mathrm{Si}$ was higher than that of $\mathrm{Fe}_{30} \mathrm{Mn}$ alloy. Other alloying elements, such as $\mathrm{Mn}, \mathrm{Co}, \mathrm{W}, \mathrm{B}, \mathrm{C}$, and $\mathrm{S}$ were found to have effects on improving the yield and ultimate strength properties, whereas the alloying element $\mathrm{Sn}$ led to a severe reduction in mechanical properties. Some studies on controlling of the manufacturing process to refine Fe-based BMs microstructures have been reported. Generally, the microstructure adjustment showed similar effects on modification of the corrosion rate.

Up to now, there is no clinical case report about Fe-based stents. Only several animal tests have been reported. Peuster et al. implanted Fe-BM stents into the descending aorta of New Zealand white rabbits and minipigs to examine their mechanical properties and biocompatibility [128]. The results demonstrated that the stent corrosion process is very slow and faster degradation rate is needed. Further studies focus on the modification of the composition and design of the stent to expedite the degradation process.

\subsection{Applications of Zn-Based BMs}

Zinc is another essential element for the human body. Normal adults contain 1.5-2.5g zinc, of which $60 \%$ exists in the muscle and $30 \%$ exists in the bone tissues. Zinc is also an important component of many enzymes; these enzymes help the synthesis of proteins and DNA, and promote 
cell regeneration and tissue metabolism $[129,130]$. According to the electrochemical principle, $\mathrm{Zn}$ has a moderate degradation rate which is faster than Fe but slower than Mg. Considering Mg-based BM degradation is too fast and Fe-based BMs degradation is too slow, Zn-based BMs are believed to be promising biodegradable metal candidates [131]. However, an obvious drawback of Zn-BMs is that pure $\mathrm{Zn}$ has very low strength and plasticity. In order to improve the mechanical properties of pure $\mathrm{Zn}$, some elements were added into Zn-based BMs. It was found that Zn-BM Zn38Ca32Mg12Yb18 showed much higher strength ( $>600 \mathrm{MPa})$ than conventional Mg based BMs ( $200 \mathrm{MPa})$. This alloy also showed slower degradation rate than pure $\mathrm{Mg}$ and hardly any hydrogen is generated during implantation. Some studies have reported in vivo results on Zn-based BMs [131]. For example, pure zinc wires were placed into the arteries of rats and their degradation rate is about $0.2 \mathrm{~mm}$ per year, a perfect value for bioabsorbable stents in the first three months. However, after that, the corrosion accelerated, so the implant did not remain in the artery too long. Therefore, precise control of the degradation rate of $\mathrm{Zn}$-based $\mathrm{BMs}$ will be a promising direction.

Along with the above three types of alloy systems, based on the principle that it is acceptable to add metal elements according to human body elements composition, $\mathrm{Ca}, \mathrm{K}, \mathrm{Na}, \mathrm{Si}, \mathrm{Se}, \mathrm{Cu}, \mathrm{Mo}, \mathrm{Sn}$, $\mathrm{Co}$ and Mn may be served as alloying elements. However, only a few new alloys containing these elements have been reported.

\section{Stents Applications}

Stenting, clinically known as percutaneous coronary intervention (PCI), has become a proven procedure for the treatment of coronary artery occlusions. During surgery, stents are delivered and placed into a narrowed coronary artery by using a catheter system that is inserted into the artery through a small incision in the arm or groin. Since its first use in biomedical applications in 1987 [132], stents have progressively been advanced from the conventional bare metal to the drug eluting and the most recent biodegradable stents [127,133].

Nowadays, biodegradable stents have been successfully applied in clinical trials [131,134]. Peeters et al. [135] reported that absorbable metal stent (AMS) (BIOTRONIK, Berlin, Germany) were implanted into 20 patients in 2005. The implanted stents were mostly degraded after six weeks. In 2005, Zartner et al. reported the first application of Mg-based stents [136]. In that case, a Lekton Magic AMS stent was successfully implanted into the pulmonary artery of a preterm baby. The degradation process had been completed after five months of implantation. In 2007, the BIOTRO-NIKGMBH and Co., Germany sponsored a series clinical trials to assess the efficacy and safety of AMSs in eight centers [137]. A total of 71 stents, $10-15 \mathrm{~mm}$ in length and 3-3.5 mm in diameter, were successfully implanted into 63 patients. That clinical trials showed good results with no myocardial infarction, subacute or late thrombosis or death of subjects during the study [138]. In 2013, Haude et al. [139] reported the first-in-man trial (BIO-SOLVE-1), which was conducted with 46 patients at five European centers. The 12-month results showed no cardiac death or stents thrombosis. As the above studies reported, the biodegradable stents had been optimized to provide much better degradation resistance than their predecessors with full degradation in 9-12 months. On 5 July 2016, the USA FDA announced the approval of Abbott's Absorb GT1 bioabsorbable cardiac stenting system, which is the first fully bioabsorbable vascular stent in the world. However, only after one year, on 14 September, Abbott Laboratories announced that they will stop selling Absorb BVS in all countries [140]. Subsequently, Boston Scientific declared abandoning its biodegradable scaffold project [141]. Although the above fully degradable stents are polymeric based products, it alerts us that the design and evaluation of the degradability of metal stents are worthy of further study to avoid the associated potential risks when developing a new generation of BM stents.

\section{Orthopedic Applications}

Bones disease or bone fractures are very common in the clinic. Thus, fractured bone fixtures stimulate BMs to become a huge potential market in orthopedic applications [142]. Many Mg-based 
alloys such as ZEK 100, LAE442 and MgCa0.8 have been fabricated into screws for animal models and clinical trials $[13,85,143,144]$. A twelve months in vivo animal model confirmed that the Mg-based alloys showed positive osteogenetic effects after implantation. No gas generation was detected next to the implants of both. After 12 months of implantation of MgCa0.8 and LAE442 alloys, the implants showed osseointegration. Another in vivo study of a biodegradable MgYREZr-alloy screw in a rabbit model for 12 months revealed moderate bone formation with direct implant contact without a fibrous capsule. Histopathological results indicated this BM has good biocompatibility and osteoconductivity without acute, subacute, or chronic toxicity. Berglund et al. proposed a novel $\mathrm{Mg}-\mathrm{xCa}-\mathrm{ySr}$ system $(\mathrm{x}=0.5-7.0 \mathrm{wt} \% ; \mathrm{y}=0.5-3.5 \mathrm{wt} \%)$ for biodegradable orthopedic implant applications. In vitro cytotoxicity testing indicated that the $\mathrm{Mg}-1.0 \mathrm{Ca}-0.5 \mathrm{Sr}$ alloy is the most promising alloy for orthopedic implant applications since it showed lower degradation rate with no significant toxicity to MC3T3-E1 osteoblasts and a compressive strength of $274 \pm 4 \mathrm{MPa}$ [138]. Some other Mg-based system alloys also showed promising applications. MgCa0.8 screws showed comparable biomechanical properties as S316L screws in the first 2-3 weeks of implantation. The MgYREZr alloy showed equivalent strength to a standard titanium screw [139]. Figure 11 shows two main application products of BMs, i.e., stents and orthopedic implants [145].

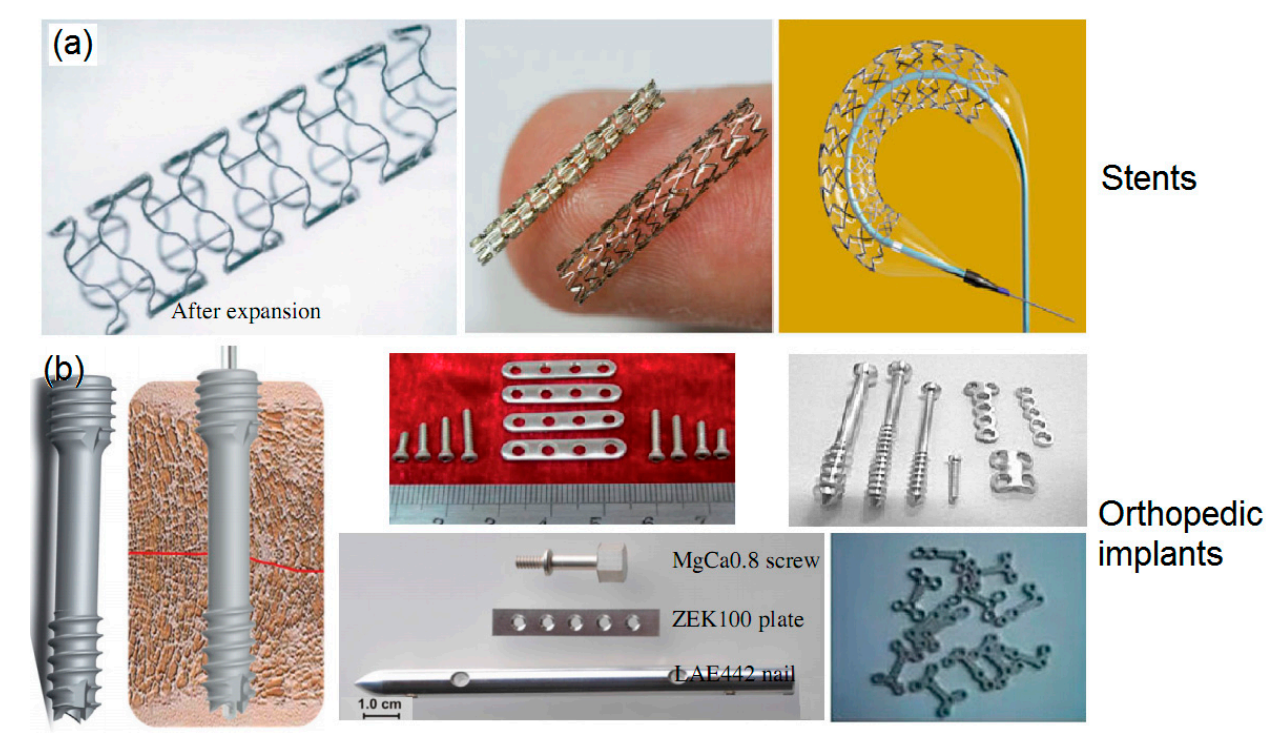

Figure 11. Two main application products: (a) stents and (b) orthopedic implants made of BMs.

\section{Concluding Remarks and Perspectives}

The biological functional design of metallic biomaterials is very important for clinical applications. The future direction for metallic implants goes toward the combination of suitable mechanical properties and multiple bio-functionalities. The study of innovative metallic implants is one of the most interesting research topics at the forefront of biomaterials. In comparison to the traditional bioinert metallic implants, BMs are representative bioactive biomaterials, and it should develop toward "third-generation biomaterials". How to make sure the BMs play more active role in heal tissues, not simply as a tissue engineering scaffold, is the topic of continuous research. The interface between the bioactive implants and the host keeps a dynamic balance. The biodegradable rate of the implants, as well as the biodegradation products from implants, need a comprehensive consideration when designing novel metallic implants. The future trends and development direction of BMs are towards multifunctional capabilities. For example, novel metallic implants may provide temporary scaffolds with both structure size and mechanical strength requirements, with loading of drugs to prevent inflammatory reactions during implantation, and its biodegradation products/elements help local tissues reconstruction. 
Benefiting from the development of some new manufacturing technologies, the metals can be directly fabricated into implants with multiple biological functions. For example, by using 3D printing technology, the implants can be printed into any porous structures with adjustable mechanical properties. It has been possible to create a controllable porous, interconnected architecture via 3D printing technology. By using select laser melting methods, a metal 3D printing technique, we can generate complex, customizable titanium implants from metal powders. Biomimetic porous structures have been designed to allow cell and fluid transportation and bony ingrowth. It is found that the 3DP method is capable of replicating highly accurate porous structure implants with errors in the range of $20 \mu \mathrm{m}$. Studies also demonstrated that the 3D printed implants show tensile mechanical properties similar to those of natural bone, and it presented an estimated corrosion rate because of 3DP has the ability to combine different materials in any space. Based on these developments, we believe that $3 \mathrm{D}$ printing is a promising technology for biomedical applications, and brings new opportunity for fabrication of novel metallic biomaterials with multiple biofuncitons.

The development of novel metal implants with different biological functions provides effective approaches for tissue repair and regeneration. There are three important design criteria for the new generation of metallic biomaterials: (1) mechanical properties with biomimetic design to those of host tissues; (2) porous structural design and surface bioactivation treatment; and (3) biodegradable metal design to match tissue regeneration. Third-generation metallic biomaterials are being designed to stimulate specific functions to meet diverse implant requirements, to perform as a drug delivery system, or to have cell and tissue specific properties. The separate design criteria of bioactive materials and resorbable materials need to converge. It is time to consider a shift toward multiple biological function design in metallic implants for the purpose of regeneration of natural tissues.

Acknowledgments: This work was financially supported by the National Key Research and Development Program of China (Grant No. 2016YFC1102000), and the "111" Project of China (Grant No. B16033). Science and Technology Support Program of Sichuan Province (Grant No. 2016GZ0196, Grant No. 2016SZ0003). Sichuan Province Major Scientific \& Technological Achievements Transformation Demonstration Project (Grant No. 2016CZYD0004). Sichuan Province Science \& Technology Department key projects (Grant No. 2017SZ0001).

Author Contributions: Changchun Zhou, Hongsong Fan and Xingdong Zhang conceived and designed the review; Ping Song, Hongyuan Fan and Qing Jiang performed the literatures collection; Yujiang Fan and Ke Yang analyzed the data; Ke Yang, Changchun Zhou and Yu Chen wrote the paper. All authors read and approved the manuscript.

Conflicts of Interest: The authors declare no conflict of interest.

\section{References}

1. Xu, G.; Fu, X.; Du, C.; Ma, J.; Li, Z.; Tian, P.; Zhang, T.; Ma, X. Biomechanical comparison of mono-segment transpedicular fixation with short-segment fixation for treatment of thoracolumbar fractures: A finite element analysis. Proc. Inst. Mech. Eng. J. Part H Eng. Med. 2014, 228, 1005-1013. [CrossRef] [PubMed]

2. Guo, B.; Lei, B.; Li, P.; Ma, P.X. Functionalized scaffolds to enhance tissue regeneration. Regen. Biomater. 2015, 2, 47-57. [CrossRef] [PubMed]

3. Pownder, S.L.; Koff, M.F.; Shah, P.H.; Fortier, L.A.; Potter, H.G. Magnetic resonance imaging of an equine fracture model containing stainless steel metal implants. Equine Vet. J. 2016, 48, 321-325. [CrossRef] [PubMed]

4. Hudetz, D.; Ursic Hudetz, S.; Harris, L.G.; Luginbuhl, R.; Friederich, N.F.; Landmann, R. Weak effect of metal type and ica genes on staphylococcal infection of titanium and stainless steel implants. Clin. Microbiol. Infect. 2008, 14, 1135-1145. [CrossRef] [PubMed]

5. Hench, L.L.; Polak, J.M. Third-generation biomedical materials. Science 2002, 295. [CrossRef] [PubMed]

6. Hench, L.L.; Xynos, I.D.; Polak, J.M. Bioactive glasses for in situ tissue regeneration. J. Biomater. Sci. Polym. Ed. 2004, 15, 543-562. [CrossRef] [PubMed]

7. Hench, L.L. The story of Bioglass. J. Mater. Sci. Mater. Med. 2006, 17, 967-978. [CrossRef] [PubMed]

8. Hench, L.L.; Boccaccini, A.R.; Day, R.M.; Gabe, S.M. Third-generation gene-activating biomaterials. Mater. Sci. Forum 2003, 426-432, 179-184. [CrossRef] 
9. Mousa, H.M.; Tiwari, A.P.; Kim, J.; Adhikari, S.P.; Park, C.H.; Kim, C.S. A novel in situ deposition of hydroxyapatite nanoplates using anodization/hydrothermal process onto magnesium alloy surface towards third generation biomaterials. Mater. Lett. 2016, 164, 144-147. [CrossRef]

10. Vallittu, P.K. Bioactive glass-containing cranial implants: An overview. J. Mater. Sci. 2017, 52, 8772-8784. [CrossRef]

11. Chen, X.H.; Geng, Y.X.; Pan, F.S. Research progress in magnesium alloys as functional materials. Rare Met. Mater. Eng. 2016, 45, 2269-2274.

12. Chen, Y.Q.; Zhang, W.T.; Maitz, M.F.; Chen, M.Y.; Zhang, H.; Mao, J.L.; Zhao, Y.C.; Huang, N.; Wan, G.J. Comparative corrosion behavior of $\mathrm{Zn}$ with $\mathrm{Fe}$ and $\mathrm{Mg}$ in the course of immersion degradation in phosphate buffered saline. Corros. Sci. 2016, 111, 541-555. [CrossRef]

13. Liu, X.W.; Sun, J.K.; Zhou, F.Y.; Yang, Y.H.; Chang, R.C.; Qiu, K.J.; Pu, Z.J.; Li, L.; Zheng, Y.F. Micro-alloyingwith $\mathrm{Mn}$ in $\mathrm{Zn}-\mathrm{Mg}$ alloy for future biodegradable metals application. Mater. Des. 2016, 94, 95-104. [CrossRef]

14. Ma, J.; Zhao, N.; Betts, L.; Zhu, D.H. Bio-adaption between magnesium alloy stent and the blood vessel: A review. J. Mater. Sci. Technol. 2016, 32, 815-826. [CrossRef] [PubMed]

15. Miura, C.; Shimizu, Y.; Imai, Y.; Mukai, T.; Yamamoto, A.; Sano, Y.; Ikeo, N.; Isozaki, S.; Takahashi, T.; Oikawa, M.; et al. In vivo corrosion behaviour of magnesium alloy in association with surrounding tissue response in rats. Biomed. Mater. 2016, 11. [CrossRef] [PubMed]

16. Torne, K.; Larsson, M.; Norlin, A.; Weissenrieder, J. Degradation of zinc in saline solutions, plasma, and whole blood. J. Biomed. Mater. Res. B 2016, 104, 1141-1151. [CrossRef] [PubMed]

17. Bian, D.; Zhou, W.R.; Liu, Y.; Li, N.; Zheng, Y.F.; Sun, Z.L. Fatigue behaviors of HP-Mg, Mg-Ca and Mg-Zn-Ca biodegradable metals in air and simulated body fluid. Acta Biomater. 2016, 41, 351-360. [CrossRef] [PubMed]

18. Su, J.S.; Xu, H.Z.; Sun, J.; Gong, X.; Zhao, H. Dual delivery of BMP-2 and bFGF from a new nano-composite scaffold, loaded with vascular stents for large-size mandibular defect regeneration. Int. J. Mol. Sci. 2013, 14, 12714-12728. [CrossRef] [PubMed]

19. Xu, H.Z.; Su, J.S.; Sun, J.; Ren, T.B. Preparation and characterization of new nano-composite scaffolds loaded with vascular stents. Int. J. Mol. Sci. 2012, 13, 3366-3381. [CrossRef] [PubMed]

20. Gabler, C.; Zietz, C.; Gohler, R.; Fritsche, A.; Lindner, T.; Haenle, M.; Finke, B.; Meichsner, J.; Lenz, S.; Frerich, B.; et al. Evaluation of osseointegration of titanium alloyed implants modified by plasma polymerization. Int. J. Mol. Sci. 2014, 15, 2454-2464. [CrossRef] [PubMed]

21. Yang, D.H.; Moon, S.W.; Lee, D.W. Surface modification of titanium with BMP-2/GDF-5 by a heparin linker and its efficacy as a dental implant. Int. J. Mol. Sci. 2017, 18, 229. [CrossRef] [PubMed]

22. Wang, X.Z.; Zhang, Y.F.; Choukroun, J.; Ghanaati, S.; Miron, R.J. Behavior of gingival fibroblasts on Titanium implant surfaces in combination with either injectable-PRF or PRP. Int. J. Mol. Sci. 2017, 18. [CrossRef] [PubMed]

23. Zhao, X.J.; Wang, T.; Qian, S.; Liu, X.Y.; Sun, J.Y.; Li, B. Silicon-doped titanium dioxide nanotubes promoted bone formation on titanium implants. Int. J. Mol. Sci. 2016, 17, 292. [CrossRef] [PubMed]

24. Matena, J.; Petersen, S.; Gieseke, M.; Kampmann, A.; Teske, M.; Beyerbach, M.; Escobar, H.M.; Haferkamp, H.; Gellrich, N.C.; Nolte, I. SLM produced porous titanium implant improvements for enhanced vascularization and osteoblast seeding. Int. J. Mol. Sci. 2015, 16, 7478-7492. [CrossRef] [PubMed]

25. Chowdhary, R.; Jimbo, R.; Thomsen, C.; Carlsson, L.; Wennerberg, A. Biomechanical evaluation of macro and micro designed screw-type implants: An insertion torque and removal torque study in rabbits. Clin. Oral Implants Res. 2013, 24, 342-346. [CrossRef] [PubMed]

26. Zhang, Q.; Cheng, C.K.; Wei, H.W.; Dong, X.; Chen, Y.T.; Lai, Y.S.; Wang, Y. Biomechanical comparisons between a new avascular necrosis of femaral head stem based on Chinese patients with avascular necrosis and two other designs. Chin. Med. J. Peking 2013, 126, 1918-1924.

27. Cheng, C.K.; McClean, C.J.; Lai, Y.S.; Chen, W.C.; Huang, C.H.; Lin, K.J.; Chang, C.M. Biomechanical considerations in the design of high-flexion total knee replacements. Sci. World J. 2014. [CrossRef] [PubMed]

28. Prashanth, S.E.K.G.; Attar, H.; Chaubey, A.K.; Cao, G.H.; Zhang, L.C. Evaluation of mechanical and wear properties of TixNb7Fe alloys designed for biomedical applications. Mater. Des. 2016, 111, 592-599.

29. Attar, H.; Ehtemam-Haghighi, S.; Kent, D.; Wu, X.H.; Dargusch, M.S. Comparative study of commercially pure titanium produced by laser engineered net shaping, selective laser melting and casting processes. Mater. Sci. Eng. A Struct. 2017, 705, 385-393. [CrossRef] 
30. Ansari, F.; Pack, L.K.; Brooks, S.S.; Morrison, T.M. Design considerations for studies of the biomechanical environment of the femoropopliteal arteries. J. Vasc. Surg. 2013, 58, 804-813. [CrossRef] [PubMed]

31. Jones, R.K.; Zhang, M.; Laxton, P.; Findlow, A.H.; Liu, A.M. The biomechanical effects of a new design of lateral wedge insole on the knee and ankle during walking. Hum. Mov. Sci. 2013, 32, 596-604. [CrossRef] [PubMed]

32. Pereira, V.A.; Iamashita, H.Y.; Monnazzi, M.S.; Gabrielli, M.F.R.; Vaz, L.G.; Passeri, L.A. In vitro biomechanical evaluation of sagittal split osteotomy fixation with a specifically designed miniplate. Int. J. Oral Maxillofac. Surg. 2013, 42, 316-320. [CrossRef] [PubMed]

33. Lin, H.M.; Liu, C.L.; Pan, Y.N.; Huang, C.H.; Shih, S.L.; Wei, S.H.; Chen, C.S. Biomechanical analysis and design of a dynamic spinal fixator using topology optimization: A finite element analysis. Med. Biol. Eng. Comput. 2014, 52, 499-508. [CrossRef] [PubMed]

34. Hu, Z.; Thiyagarajan, K.; Bhusal, A.; Letcher, T.; Fan, Q.H.; Liu, Q.; Salem, D. Design of ultra-lightweight and high-strength cellular structural composites inspired by biomimetics. Compos. Part B Eng. 2017, 121, $108-121$. [CrossRef]

35. Okulov, I.V.; Volegov, A.S.; Attar, H.; Bonisch, M.; Ehternam-Haghighi, S.; Calin, M.; Eckert, J. Composition optimization of low modulus and high-strength TiNb-based alloys for biomedical applications. J. Mech. Behav. Biomed. 2017, 65, 866-871. [CrossRef] [PubMed]

36. Suer, B.T.; Kocyigit, I.D.; Kaman, S.; Tuz, H.H.; Tekin, U.; Atil, F. Biomechanical evaluation of a new design titanium miniplate for the treatment of mandibular angle fractures. Int. J. Oral Maxillofac. Surg. 2014, 43, 841-845. [CrossRef] [PubMed]

37. Serhan, M.; Verim, O.; Eroglu, M.; Altinel, L.; Gokce, B.; Tasgetiren, S. Biomechanical evaluation of syndesmotic screw design via finite element analysis and Taguchi's method. JAPMA 2015, 105, 14-21.

38. Liu, D.X.; Hua, Z.K.; Yan, X.Y.; Jin, Z.M. Design and biomechanical study of a novel adjustable hemipelvic prosthesis. Med. Eng. Phys. 2016, 38, 1416-1425. [CrossRef] [PubMed]

39. Khan, Y.M.; Nair, L.S. Review of "Biomaterials for Musculoskeletal Regeneration: Concepts, by Bikramjit Basu, Indian Institute of Metals Series, Springer Nature (2016)" and "Biomaterials for Musculoskeletal Regeneration: Applications, by Bikramjit Basu and Sourabh Ghosh, Indian Institute of Metals Series, Springer Nature (2016)". J. Mater. Sci. 2017. [CrossRef]

40. Zhou, J.J.; Zhao, M.; Liu, D.; Liu, H.Y.; Du, C.F. Biomechanical Property of a Newly Designed Assembly Locking Compression Plate: Three-Dimensional Finite Element Analysis. J. Healthc. Eng. 2017. [CrossRef] [PubMed]

41. Muiznieks, L.D.; Keeley, F.W. Biomechanical Design of Elastic Protein Biomaterials: A Balance of Protein Structure and Conformational Disorder. ACS Biomater. Sci. Eng. 2017, 3, 661-679. [CrossRef]

42. Liu, J.T.; Chen, W.C.; Wei, H.W. Biomechanical evaluation of a dynamic fusion cage design for cervical spine: A finite element study. Adv. Mech. Eng. 2017, 9. [CrossRef]

43. Tang, Z.X.; Li, L.Y.; Guo, W.P.; Jiang, W.T.; Fan, Y.B. Topology optimization on configuration of titanium reconstruction plate for bridging mandibular angle defect. J. Med. Biomech. 2014, 29, 167-173.

44. Guo, W.; Li, Y.; Tang, Z.; Jiang, W.; Fan, Y. Finite element modeling of the mandible with temporomandibular joint. J. Biomed. Eng. Res. 2013, 3, 57-65. [CrossRef]

45. Wan, Z.P.; Wang, C.; Jiang, W.T.; Huang, Z.Y.; Wang, Q.Y. On the effect of void defects on stress distribution of Ti-6Al-4V alloy fatigue specimen in 3D printing. J. Exp. Mech. 2017, 32, 1-8.

46. Zunino, P.; D’Aangelo, C.; Petrini, L.; Vergara, C.; Capelli, C. Numerical simulation of drug eluting coronary stents: Mechanics, fluid dynamics and drug release. Comput. Methods Appl. Mech. Eng. 2009, 198, 3633-3644. [CrossRef]

47. Chen, Y.; Xiong, Y.; Jiang, W.; Wong, M.S.; Yan, F.; Wang, Q.; Fan, Y. Numerical simulation on the effects ofdrug-eluting stents with different bending angles on hemodynamics and drug distribution. Med. Biol. Eng. Comput. 2016, 54, 1859-1867. [CrossRef] [PubMed]

48. Chen, Y. Numerical study on effects of drug-coating position of drug-eluting stents on drug concentration. J. Med. Biol. Eng. 2015, 34, 487-494. [CrossRef]

49. Shah, F.A.; Snis, A.; Matic, A.; Thomsen, P.; Palmquist, A. 3D printed Ti6Al4V implant surface promotes bone maturation and retains a higher density of less aged osteocytes at the bone-implant interface. Acta Biomater. 2016, 30, 357-367. [CrossRef] [PubMed] 
50. Wu, Y.; Liu, Q.; Fu, J.; Li, Q.; Hui, D. Dynamic crash responses of bio-inspired aluminum honeycomb sandwich structures with CFRP panels. Compos. Part B Eng. 2017, 121, 122-133. [CrossRef]

51. Galdos, M.V.G.; Pastore, J.I.; Ballarre, J.; Cere, S.M. Dual-surface modification of titanium alloy with anodizing treatment and bioceramic particles for enhancing prosthetic devices. J. Mater. Sci. 2017, 52, 9151-9165. [CrossRef]

52. Habibovic, P.; Gbureck, U.; Doillon, C.J.; Bassett, D.C.; van Blitterswijk, C.A.; Barralet, J.E. Osteoconduction and osteoinduction of low-temperature 3D printed bioceramic implants. Biomaterials 2008, 29, 944-953. [CrossRef] [PubMed]

53. Liu, A.; Xue, G.H.; Sun, M.; Shao, H.F.; Ma, C.Y.; Gao, Q.; Gou, Z.R.; Yan, S.G.; Liu, Y.M.; He, Y. 3D Printing Surgical Implants at the clinic: A Experimental Study on Anterior Cruciate Ligament Reconstruction. Sci. Rep. 2016, 6. [CrossRef] [PubMed]

54. Mobbs, R.J.; Coughlan, M.; Thompson, R.; Sutterlin, C.E.; Phan, K. The utility of 3D printing for surgical planning and patient-specific implant design for complex spinal pathologies: Case report. J. Neurosurg. Spine 2017, 26, 513-518. [CrossRef] [PubMed]

55. Palmquist, A.; Shah, F.A.; Emanuelsson, L.; Omar, O.; Suska, F. A technique for evaluating bone ingrowth into 3D printed, porous Ti6Al4V implants accurately using X-ray micro-computed tomography and histomorphometry. Micron 2017, 94, 1-8. [CrossRef] [PubMed]

56. Tran, P.; Ngo, T.D.; Ghazlan, A.; Hui, D. Bimaterial 3D printing and numerical analysis of bio-inspired composite structures under in-plane and transverse loadings. Compos. Part B Eng. 2017, 108, 210-223. [CrossRef]

57. Yang, F.; Chen, C.; Zhou, Q.R.; Gong, Y.M.; Li, R.X.; Li, C.C.; Klampfl, F.; Freund, S.; Wu, X.W.; Sun, Y.; et al. Laser beam melting 3D printing of Ti6Al4V based porous structured dental implants: Fabrication, biocompatibility analysis and photoelastic study. Sci. Rep. 2017, 7. [CrossRef] [PubMed]

58. Zhang, Z.; Wang, B.; Hui, D.; Qiu, J.; Wang, S. 3D bioprinting of soft materials-based regenerative vascular structures and tissues. Compos. Part B Eng. 2017, 123, 279-291. [CrossRef]

59. Wang, X.; Jiang, M.; Zhou, Z.; Gou, J.; Hui, D. 3D printing of polymer matrix composites: A review and prospective. Compos. Part B Eng. 2017, 110, 442-458. [CrossRef]

60. Pandele, A.M.; Ionita, M.; Crica, L.; Vasile, E.; Iovu, H. Novel Chitosan-poly(vinyl alcohol)/graphene oxide biocomposites 3D porous scaffolds. Compos. Part B Eng. 2017, 126, 81-87. [CrossRef]

61. Pei, X.; Zhang, B.; Fan, Y.; Zhu, X.; Sun, Y.; Wang, Q.; Zhang, X.; Zhou, C. Bionic mechanical design of titanium bone tissue implants and 3D printing manufacture. Mater. Lett. 2017. [CrossRef]

62. Momeni, F.; Hassani, N.S.M.M.; Liu, X.; Ni, J. A review of 4D printing. Mater. Des. 2017, 122, 42-79. [CrossRef]

63. Kaczmarek, M.; Jurczyk, K.; Koper, J.K.; Paszel-Jaworska, A.; Romaniuk, A.; Lipinska, N.; Zurawski, J.; Urbaniak, P.; Jakubowicz, J.; Jurczyk, M.U. In vitro biocompatibility of anodized titanium with deposited silver nanodendrites. J. Mater. Sci. 2016, 51, 5259-5270. [CrossRef]

64. Lux, F.; Zeisler, R. Investigations of corrosive deposition of components of metal implants and of behavior of biological trace-elements in metallosis tissue by means of instrumental multi-element activation-analysis. J. Radioanal. Nucl. Chem. 1974, 19, 289-297. [CrossRef]

65. Boke, F.; Schickle, K.; Fischer, H. Biological activation of inert ceramics: Recent advances using tailored self-assembled monolayers on implant ceramic surfaces. Materials 2014, 7, 4473-4492. [CrossRef] [PubMed]

66. Ostrovska, L.; Vistejnova, L.; Dzugan, J.; Slama, P.; Kubina, T.; Ukraintsev, E.; Kubies, D.; Kralickova, M.; Kalbacova, M.H. Biological evaluation of ultra-fine titanium with improved mechanical strength for dental implant engineering. J. Mater. Sci. 2016, 51, 3097-3110. [CrossRef]

67. Ribeiro, A.M.; Flores-Sahagun, T.H.S.; Paredes, R.C. A perspective on molybdenum biocompatibility and antimicrobial activity for applications in implants. J. Mater. Sci. 2016, 51, 2806-2816. [CrossRef]

68. Choy, M.-T.; Tang, C.-Y.; Chen, L.; Law, W.-C.; Tsui, C.-P.; Lu, W.W. Microwave assisted- synthesis of porous titanium/calcium phosphate composites and their apatite-forming capability. Compos. Part B Eng. 2015, 83, 50-57. [CrossRef]

69. Balas, F.; Kawashita, M.; Nakamura, T.; Kokubo, T. Formation of bone-like apatite on organic polymers treated with a silane-coupling agent and a titania solution. Biomaterials 2006, 27, 1704-1710. [CrossRef] [PubMed] 
70. Leonor, I.B.; Balas, F.; Kawashita, M.; Reis, R.L.; Kokubo, T.; Nakamura, T. Biomimetic apatite formation on different polymeric microspheres modified with calcium silicate solutions. Key Eng. Mater. 2006, 309-311, 279-282. [CrossRef]

71. Leonor, I.B.; Kim, H.M.; Balas, F.; Kawashita, M.; Reis, R.L.; Kokubo, T.; Nakamura, T. Formation of bone-like apatite on polymeric surfaces modified with-SO ${ }_{3} \mathrm{H}$ groups. Adv. Mater. Forum III 2006, 514-516, 966-969. [CrossRef]

72. Zhou, C.C.; Ye, X.J.; Fan, Y.J.; Qing, F.Z.; Chen, H.J.; Zhang, X.D. Synthesis and characterization of CaP/Col composite scaffolds for load-bearing bone tissue engineering. Compos. Part B Eng. 2014, 62, 242-248. [CrossRef]

73. Pattanayak, D.K.; Yamaguchi, S.; Matsushita, T.; Nakamura, T.; Kokubo, T. Apatite-forming ability of titanium in terms of $\mathrm{pH}$ of the exposed solution. J. R. Soc. Interface 2012, 9, 2145-2155. [CrossRef] [PubMed]

74. Kokubo, T.; Yamaguchi, S. Growth of novel ceramic layers on metals via chemical and heat treatments for inducing various biological functions. Front. Bioeng. Biotechnol. 2015, 3, 176. [CrossRef] [PubMed]

75. Lin, J.H.; Chang, C.H.; Chen, Y.S.; Lin, G.T. Formation of bone-like apatite on titanium filaments incubated in a simulated body fluid by using an electrochemical method. Compos. Part A Appl. Sci. Manuf. 2007, 38, 535-539. [CrossRef]

76. Cui, X.Y.; Kim, H.M.; Kawashita, M.; Wang, L.B.; Xiong, T.Y.; Kokubo, T.; Nakamura, T. Apatite formation on anodized Ti-6Al-4V alloy in simulated body fluid. Met. Mater. Int. 2010, 16, 407-412. [CrossRef]

77. Chavan, P.N.; Bahir, M.M.; Mene, R.U.; Mahabole, M.P.; Khairnar, R.S. Study of nanobiomaterial hydroxyapatite in simulated body fluid: Formation and growth of apatite. Mater. Sci. Eng. B Adv. 2010, 168, 224-230. [CrossRef]

78. Kang, K.-T.; Koh, Y.-G.; Son, J.; Yeom, J.S.; Park, J.-H.; Kim, H.-J. Biomechanical evaluation of pedicle screw fixation system in spinal adjacent levels using polyetheretherketone, carbon-fiber-reinforced polyetheretherketone, and traditional titanium as rod materials. Compos. Part B Eng. 2017, 130, 248-256. [CrossRef]

79. Yoshida, E.; Hayakawa, T. Quantitative analysis of apatite formation on titanium and zirconia in a simulated body fluid solution using the quartz crystal microbalance method. Adv. Mater. Sci. Eng. 2017. [CrossRef]

80. Zhao, C.Y.; Zhu, X.D.; Yuan, T.; Fan, H.S.; Zhang, X.D. Fabrication of biomimetic apatite coating on porous titanium and their osteointegration in femurs of dogs. Mater. Sci. Eng. C 2010, 30, 98-104.

81. Gu, X.N.; Xie, X.H.; Li, N.; Zheng, Y.F.; Qin, L. In vitro and in vivo studies on a Mg-Sr binary alloy system developed as a new kind of biodegradable metal. Acta Biomater. 2012, 8, 2360-2374. [CrossRef] [PubMed]

82. Li, H.F.; Zheng, Y.F.; Qin, L. Progress of biodegradable metals. Prog. Nat. Sci. Mater. Int. 2014, $24,414-422$. [CrossRef]

83. Zheng, Y.F.; Gu, X.N.; Witte, F. Biodegradable metals. Mat. Sci. Eng. R Rep. 2014, 77, 1-34. [CrossRef]

84. Li, H.F.; Zheng, Y.F. Recent advances in bulk metallic glasses for biomedical applications. Acta Biomater. 2016, 36, 1-20. [CrossRef] [PubMed]

85. Wang, C.; Yang, H.T.; Li, X.; Zheng, Y.F. In vitro evaluation of the feasibility of commercial Zn alloys as biodegradable metals. J. Mater. Sci. Technol. 2016, 32, 909-918. [CrossRef]

86. Bajger, P.; Ashbourn, J.M.; Manhas, V.; Guyot, Y.; Lietaert, K.; Geris, L. Mathematical modelling of the degradation behaviour of biodegradable metals. Biomech. Model. Mechanobiol. 2016. [CrossRef] [PubMed]

87. Tang, Z.B.; Huang, H.; Niu, J.L.; Zhang, L.; Zhang, H.; Pei, J.; Tan, J.Y.; Yuan, G.Y. Design and characterizations of novel biodegradable $\mathrm{Zn}-\mathrm{Cu}-\mathrm{Mg}$ alloys for potential biodegradable implants. Mater. Des. 2017, 117, 84-94. [CrossRef]

88. Dambatta, M.S.; Izman, S.; Kurniawan, D.; Farahany, S.; Yahaya, B.; Hermawan, H. Influence of thermal treatment on microstructure, mechanical and degradation properties of Zn-3Mg alloy as potential biodegradable implant material. Mater. Des. 2015, 85, 431-437. [CrossRef]

89. Piela, K.; Wrobel, M.; Sztwiertnia, K.; Jaskowski, M.; Kawalko, J.; Bieda, M.; Kiper, M.; Jarzebska, A. Zinc subjected to plastic deformation by complex loading and conventional extrusion: Comparison of the microstructure and mechanical properties. Mater. Des. 2017, 117, 111-120. [CrossRef]

90. Cacciotti, I. Bivalent cationic ions doped bioactive glasses: The influence of magnesium, zinc, strontium and copper on the physical and biological properties. J. Mater. Sci. 2017, 52, 8812-8831. [CrossRef] 
91. Almutairi, A.; Sun, Z.H.; Al Safran, Z.; Poovathumkadavi, A.; Albader, S.; Ifdailat, H. Optimal scanning protocols for dual-energy CT angiography in peripheral arterial stents: An in vitro phantom study. Int. J. Mol. Sci. 2015, 16, 11531-11549. [CrossRef] [PubMed]

92. Silva, C.L.P.; Oliveira, A.C.; Costa, C.G.F.; Figueiredo, R.B.; Leite, M.D.; Pereira, M.M.; Lins, V.F.C.; Langdon, T.G. Effect of severe plastic deformation on the biocompatibility and corrosion rate of pure magnesium. J. Mater. Sci. 2017, 52, 5992-6003. [CrossRef]

93. Kim, Y.K.; Park, I.S.; Lee, K.B.; Lee, S.J.; Bae, T.S.; Lee, M.H. Characterization and biocompatibility of a calcium-containing AZ31B alloy as a biodegradable material. J. Mater. Sci. 2015, 50, 4672-4682. [CrossRef]

94. Gao, H.; Ye, W.B.; Zhang, Z.; Gao, L.L. Ratcheting behavior of ZEK100 magnesium alloy with various loading conditions and different immersing time. J. Mater. Res. 2017, 32, 2143-2152. [CrossRef]

95. Gao, H.; Zhang, M.; Zhao, J.; Gao, L.L.; Li, M.S. In vitro and in vivo degradation and mechanical properties of ZEK100 magnesium alloy coated with alginate, chitosan and mechano-growth factor. Mater. Sci. Eng. C Mater. Biol. Appl. 2016, 63, 450-461. [CrossRef] [PubMed]

96. Li, H.; He, W.; Pang, S.; Liaw, P.K.; Zhang, T. In vitro responses of bone-forming MC3T3-E1 pre-osteoblasts to biodegradable Mg-based bulk metallic glasses. Mater. Sci. Eng. C Mater. Biol. Appl. 2016, 68, $632-641$. [CrossRef] [PubMed]

97. Nayak, S.; Bhushan, B.; Jayaganthan, R.; Gopinath, P.; Agarwal, R.D.; Lahiri, D. Strengthening of Mg based alloy through grain refinement for orthopaedic application. J. Mech. Behav. Biomed. Mater. 2016, 59, 57-70. [CrossRef] [PubMed]

98. Zhang, J.; Xu, C.; Jing, Y.; Lv, S.; Liu, S.; Fang, D.; Zhuang, J.; Zhang, M.; Wu, R. New horizon for high performance $\mathrm{Mg}$-based biomaterial with uniform degradation behavior: Formation of stacking faults. Sci. Rep. 2015, 5, 13933. [CrossRef] [PubMed]

99. Li, H.F.; Pang, S.J.; Liu, Y.; Sun, L.L.; Liaw, P.K.; Zhang, T. Biodegradable Mg-Zn-Ca-Sr bulk metallic glasses with enhanced corrosion performance for biomedical applications. Mater. Des. 2015, 67, 9-19. [CrossRef]

100. Christie, J.K. Atomic structure of biodegradable Mg-based bulk metallic glass. Phys. Chem. Chem. Phys. 2015, 17, 12894-12898. [CrossRef] [PubMed]

101. Ratna Sunil, B.; Sampath Kumar, T.S.; Chakkingal, U.; Nandakumar, V.; Doble, M. Nano-hydroxyapatite reinforced AZ31 magnesium alloy by friction stir processing: A solid state processing for biodegradable metal matrix composites. J. Mater. Sci. Mater. Med. 2014, 25, 975-988. [CrossRef] [PubMed]

102. Zhang, Y.; Forsyth, M.; Hinton, B.R. The effect of treatment temperature on corrosion resistance and hydrophilicity of an ionic liquid coating for Mg-based stents. ACS Appl. Mater. Interfaces 2014, 6, 18989-18997. [CrossRef] [PubMed]

103. Willbold, E.; Kalla, K.; Bartsch, I.; Bobe, K.; Brauneis, M.; Remennik, S.; Shechtman, D.; Nellesen, J.; Tillmann, W.; Vogt, C.; et al. Biocompatibility of rapidly solidified magnesium alloy RS66 as a temporary biodegradable metal. Acta Biomater. 2013, 9, 8509-8517. [CrossRef] [PubMed]

104. Chen, D.; He, Y.; Tao, H.; Zhang, Y.; Jiang, Y.; Zhang, X.; Zhang, S. Biocompatibility of magnesium-zinc alloy in biodegradable orthopedic implants. Int. J. Mol. Med. 2011, 28, 343-348. [PubMed]

105. Qin, C.; Hu, Q.; Li, Y.; Wang, Z.; Zhao, W.; Louzguine-Luzgin, D.V.; Inoue, A. Novel bioactive Fe-based metallic glasses with excellent apatite-forming ability. Mater. Sci. Eng. C Mater. Biol. Appl. 2016, 69, 513-521. [CrossRef] [PubMed]

106. Li, Y.J.; Wang, Y.G.; An, B.; Xu, H.; Liu, Y.; Zhang, L.C.; Ma, H.Y.; Wang, W.M. A practical anodic and cathodic curve intersection model to understand multiple corrosion potentials of fe-based glassy alloys in OH-contained solutions. PLoS ONE 2016, 11, e0146421. [CrossRef] [PubMed]

107. Fagali, N.S.; Grillo, C.A.; Puntarulo, S.; Fernandez Lorenzo de Mele, M.A. Cytotoxicity of corrosion products of degradable Fe-based stents: Relevance of $\mathrm{pH}$ and insoluble products. Colloids Surf. B Biointerfaces 2015, 128, 480-488. [CrossRef] [PubMed]

108. Li, S.; Wei, Q.; Li, Q.; Jiang, B.; Chen, Y.; Sun, Y. Development of Fe-based bulk metallic glasses as potential biomaterials. Mater. Sci. Eng. C Mater. Biol. Appl. 2015, 52, 235-241. [CrossRef] [PubMed]

109. Kraus, T.; Moszner, F.; Fischerauer, S.; Fiedler, M.; Martinelli, E.; Eichler, J.; Witte, F.; Willbold, E.; Schinhammer, M.; Meischel, M.; et al. Biodegradable Fe-based alloys for use in osteosynthesis: Outcome of an in vivo study after 52 weeks. Acta Biomater. 2014, 10, 3346-3353. [CrossRef] [PubMed]

110. Schinhammer, M.; Gerber, I.; Hanzi, A.C.; Uggowitzer, P.J. On the cytocompatibility of biodegradable Fe-based alloys. Mater. Sci. Eng. C Mater. Biol. Appl. 2013, 33, 782-789. [CrossRef] [PubMed] 
111. Schinhammer, M.; Hanzi, A.C.; Loffler, J.F.; Uggowitzer, P.J. Design strategy for biodegradable Fe-based alloys for medical applications. Acta Biomater. 2010, 6, 1705-1713. [CrossRef] [PubMed]

112. Li, X.; Wang, Y.; Du, C.; Yan, B. Corrosion behaviors of amorphous and nanocrystalline Fe-based alloys in $\mathrm{NaCl}$ solution. J. Nanosci. Nanotechnol. 2010, 10, 7226-7230. [CrossRef] [PubMed]

113. Mostaed, E.; Sikora-Jasinska, M.; Mostaed, A.; Loffredo, S.; Demir, A.G.; Previtali, B.; Mantovani, D.; Beanland, R.; Vedani, M. Novel Zn-based alloys for biodegradable stent applications: Design, development and in vitro degradation. J. Mech. Behav. Biomed. Mater. 2016, 60, 581-602. [CrossRef] [PubMed]

114. Yao, C.; Wang, Z.; Tay, S.L.; Zhu, T.; Gao, W. Effects of Mg on microstructure and corrosion properties of Zn-Mg alloy. J. Alloys Compd. 2014, 602, 101-107. [CrossRef]

115. Bowen, P.K.; Drelich, J.; Goldman, J. Zinc exhibits ideal physiological corrosion behavior for bioabsorbable stents. Adv. Mater. 2013, 25, 2577-2582. [CrossRef] [PubMed]

116. Jiao, W.; Li, H.F.; Zhao, K.; Bai, H.Y.; Wang, Y.B.; Zheng, Y.F. Development of cazn based glassy alloys as potential biodegradable bone graft substitute. J. Non-Cryst. Solids 2011, 357, 3830-3840. [CrossRef]

117. Vojtech, D.; Kubasek, J.; Serak, J.; Novak, P. Mechanical and corrosion properties of newly developed biodegradable Zn-based alloys for bone fixation. Acta Biomater. 2011, 7, 3515-3522. [CrossRef] [PubMed]

118. Saris, N.E.; Mervaala, E.; Karppanen, H.; Khawaja, J.A.; Lewenstam, A. Magnesium. An update on physiological, clinical and analytical aspects. Clin. Chim. Acta 2000, 294, 1-26. [CrossRef]

119. Ramya, M.; Sarwat, S.G.; Udhayabanu, V.; Subramanian, S.; Raj, B.; Ravi, K.R. Role of partially amorphous structure and alloying elements on the corrosion behavior of $\mathrm{Mg}$ - Zn-Ca bulk metallic glass for biomedical applications. Mater. Des. 2015, 86, 829-835. [CrossRef]

120. Berglund, I.S.; Brar, H.S.; Dolgova, N.; Acharya, A.P.; Keselowsky, B.G.; Sarntinoranont, M.; Manuel, M.V. Synthesis and characterization of $\mathrm{Mg}-\mathrm{Ca}-\mathrm{Sr}$ alloys for biodegradable orthopedic implant applications. J. Biomed. Mater. Res. B Appl. Biomater. 2012, 100, 1524-1534. [CrossRef] [PubMed]

121. Kusnierczyk, K.; Basista, M. Recent advances in research on magnesium alloys and magnesium-calcium phosphate composites as biodegradable implant materials. J. Biomater. Appl. 2016. [CrossRef] [PubMed]

122. Hampp, C.; Angrisani, N.; Reifenrath, J.; Bormann, D.; Seitz, J.M.; Meyer-Lindenberg, A. Evaluation of the biocompatibility of two magnesium alloys as degradable implant materials in comparison to titanium as non-resorbable material in the rabbit. Mater. Sci. Eng. C Mater. Biol. Appl. 2013, 33, 317-326. [CrossRef] [PubMed]

123. Hort, N.; Huang, Y.; Fechner, D.; Stormer, M.; Blawert, C.; Witte, F.; Vogt, C.; Drucker, H.; Willumeit, R.; Kainer, K.U.; et al. Magnesium alloys as implant materials-Principles of property design for Mg-RE alloys. Acta Biomater. 2010, 6, 1714-1725. [CrossRef] [PubMed]

124. Hanzi, A.C.; Gerber, I.; Schinhammer, M.; Loffler, J.F.; Uggowitzer, P.J. On the in vitro and in vivo degradation performance and biological response of new biodegradable Mg-Y-Zn alloys. Acta Biomater. 2010, 6, 1824-1833. [CrossRef] [PubMed]

125. Ding, Y.; Lin, J.; Wen, C.; Zhang, D.; Li, Y. Mechanical properties, in vitro corrosion and biocompatibility of newly developed biodegradable Mg-Zr-Sr-Ho alloys for biomedical applications. Sci. Rep. 2016, 6, 31990. [CrossRef] [PubMed]

126. Li, H.F.; Yang, H.T.; Zheng, Y.F.; Zhou, F.Y.; Qiu, K.J.; Wang, X. Design and characterizations of novel biodegradable ternary Zn-based alloys with IIA nutrient alloying elements $\mathrm{Mg}$, Ca and Sr. Mater. Des. 2015, 83, 95-102. [CrossRef]

127. Hermawan, H.; Purnama, A.; Dube, D.; Couet, J.; Mantovani, D. Fe-Mn alloys for metallic biodegradable stents: Degradation and cell viability studies. Acta Biomater. 2010, 6, 1852-1860. [CrossRef] [PubMed]

128. Peuster, M.; Wohlsein, P.; Brugmann, M.; Ehlerding, M.; Seidler, K.; Fink, C.; Brauer, H.; Fischer, A.; Hausdorf, G. A novel approach to temporary stenting: Degradable cardiovascular stents produced from corrodible metal-results 6-18 months after implantation into New Zealand white rabbits. Heart 2001, 86, 563-569. [CrossRef] [PubMed]

129. Seitz, J.M.; Durisin, M.; Goldman, J.; Drelich, J.W. Recent advances in biodegradable metals for medical sutures: A critical review. Adv. Healthc. Mater. 2015, 4, 1915-1936. [CrossRef] [PubMed]

130. Vojtech, D.; Kubasek, J.; Capek, J.; Pospisilova, I. Comparative Mechanical and Corrosion Studies on Magnesium, Zinc and Iron Alloys as Biodegradable Metals. Mater. Technol. 2015, 49, 877-882. [CrossRef] 
131. Bowen, P.K.; Shearier, E.R.; Zhao, S.; Guillory, R.J.; Zhao, F.; Goldman, J.; Drelich, J.W. Biodegradable Metals for Cardiovascular Stents: From Clinical Concerns to Recent Zn-Alloys. Adv. Healthc. Mater. 2016, 5, 1121-1140. [CrossRef] [PubMed]

132. Sigwart, U.; Puel, J.; Mirkovitch, V.; Joffre, F.; Kappenberger, L. Intravascular stents to prevent occlusion and restenosis after transluminal angioplasty. N. Engl. J. Med. 1987, 316, 701-706. [CrossRef] [PubMed]

133. Hermawan, H.; Dube, D.; Mantovani, D. Degradable metallic biomaterials: Design and development of Fe-Mn alloys for stents. J. Biomed. Mater. Res. Part A 2010, 93, 1-11. [CrossRef] [PubMed]

134. Moravej, M.; Mantovani, D. Biodegradable metals for cardiovascular stent application: Interests and new opportunities. Int. J. Mol. Sci. 2011, 12, 4250-4270. [CrossRef] [PubMed]

135. Peeters, P.; Bosiers, M.; Verbist, J.; Deloose, K.; Heublein, B. Preliminary results after application of absorbable metal stents in patients with critical limb ischemia. J. Endovasc. Ther. 2005, 12, 1-5. [CrossRef] [PubMed]

136. Zartner, P.; Cesnjevar, R.; Singer, H.; Weyand, M. First successful implantation of a biodegradable metal stent into the left pulmonary artery of a preterm baby. Catheter. Cardiovasc. Interv. 2005, 66, 590-594. [CrossRef] [PubMed]

137. Erbel, R.; Di Mario, C.; Bartunek, J.; Bonnier, J.; de Bruyne, B.; Eberli, F.R.; Erne, P.; Haude, M.; Heublein, B.; Horrigan, M.; et al. Temporary scaffolding of coronary arteries with bioabsorbable magnesium stents: A prospective, non-randomised multicentre trial. Lancet 2007, 369, 1869-1875. [CrossRef]

138. Chen, Y.J.; Xu, Z.G.; Smith, C.; Sankar, J. Recent advances on the development of magnesium alloys for biodegradable implants. Acta Biomater. 2014, 10, 4561-4573. [CrossRef] [PubMed]

139. Haude, M.; Erbel, R.; Erne, P.; Verheye, S.; Degen, H.; Vermeersch, P.; Weissman, N.; Prati, F.; Bruining, N.; Waksman, R.; et al. Safety and performance of the DRug-Eluting Absorbable Metal Scaffold (DREAMS) in patients with de novo coronary lesions: 3-year results of the prospective, multicentre, first-in-man BIOSOLVE-I trial. Eurointervention 2016, 12, e160-e166. [CrossRef] [PubMed]

140. Our Vascular Products Represent Deep Collaboration between Scientists, Doctors, and Patients over Decades. Available online: https:/ / www.vascular.abbott/int/products/products-home.html (accessed on 18 December 2017).

141. Newsroom. Available online: http://news.bostonscientific.com/ (accessed on 18 December 2017).

142. Affatato, S.; Ruggiero, A.; Merola, M.; Logozzo, S. Does metal transfer differ on retrieved Biolox Delta composites femoral heads? Surface investigation on three Biolox generations from a biotribological point of view. Compos. Part B Eng. 2017, 113, 164-173. [CrossRef]

143. Liu, X.W.; Sun, J.K.; Yang, Y.H.; Zhou, F.Y.; Pu, Z.J.; Li, L.; Zheng, Y.F. Microstructure, mechanical properties, in vitro degradation behavior and hemocompatibility of novel $\mathrm{Zn}-\mathrm{Mg}$-Sr alloys as biodegradable metals. Mater. Lett. 2016, 162, 242-245. [CrossRef]

144. Saleh, M.M.; Touny, A.H.; Al-Omair, M.A.; Saleh, M.M. Biodegradable/biocompatible coated metal implants for orthopedic applications. Bio-Med. Mater. Eng. 2016, 27, 87-99. [CrossRef] [PubMed]

145. Ding, W. Opportunities and challenges for the biodegradable magnesium alloys as next-generation biomaterials. Regen. Biomater. 2016, 3, 79-86. [CrossRef] [PubMed]

(c) 2017 by the authors. Licensee MDPI, Basel, Switzerland. This article is an open access article distributed under the terms and conditions of the Creative Commons Attribution (CC BY) license (http:/ / creativecommons.org/licenses/by/4.0/). 